ERNEST IRLANDQ LAWRENGE GERRELEY NATU⿴NAL LABGRATGRY

Flow Dynamics and Potential for Biodegradation of Organic Contaminants in Fractured Rock Vadose Zones

J.T. Geller, H-Y. Holman, G. Su, T-S. Liou, M.S. Conrad, K. Pruess, and J.C. Hunter-Cevera Earth Sciences Division MAR 291999 OSTI

December 1998 


\section{DISCLAIMER}

This document was prepared as an account of work sponsored by the United States Government. While this document is believed to contain correct information, neither the United States Government nor any agency thereof, nor The Regents of the University of California, nor any of their employees, makes any warranty, express or implied, or assumes any legal responsibility for the accuracy, completeness, or usefulness of any information, apparatus, product, or process disclosed, or represents that its use would not infringe privately owned rights. Reference herein to any specific commercial product, process, or service by its trade name, trademark, manufacturer, or otherwise, does not necessarily constitute or imply its endorsement, recommendation, or favoring by the United States Government or any agency thereof, or The Regents of the University of California. The views and opinions of authors expressed herein do not necessarily state or reflect those of the United States Government or any agency thereof, or The Regents of the University of California.

This report has been reproduced directly from the best available copy.

Available to DOE and DOE Contractors

from the Office of Scientific and Technical Information

P.O. Box 62, Oak Ridge, TN 37831

Prices available from (615) $576-8401$

Available to the public from the National Technical Information Service

U.S. Department of Commerce 5285 Port Royal Road, Springfield, VA 22161

Ernest Orlando Lawrence Berkeley National Laboratory is an equal opportunity employer. 


\section{DISCLAIMER}

Portions of this document may be illegible in electronic image products. Images are produced from the best available original document. 
LBNL-42587

\title{
Flow Dynamics and Potential for Biodegradation of Organic Contaminants in Fractured Rock Vadose Zones
}

\author{
J.T. Geller, ${ }^{1}$ H-Y. Holman, ${ }^{1}$ G. Su, ${ }^{1}$ T-S. Liou, ${ }^{2}$ \\ M.S. Conrad, ${ }^{1}$ K. Pruess, ${ }^{1}$ and J.C. Hunter-Cevera ${ }^{1}$ \\ ${ }^{1}$ Earth Sciences Division \\ Ernest Orlando Lawrence Berkeley National Laboratory \\ University of California \\ Berkeley, California 94720 \\ ${ }^{2}$ Department of Civil Engineering \\ University of California \\ Berkeley, California 94720
}

December 1998

This work was supported by the Director, Office of Energy Research, Office of Health and Environmental Sciences, Biological and Environmental Research Program, of the U.S. Department of Energy under Contract No. DE-AC03-76SF00098. 


\begin{abstract}
We present an experimental approach for investigating the potential for bioremediation of volatile organic chemicals (VOCs) in fractured-rock vadose zones. This approach is based on the coupling of fluid flow dynamics and biotransformation processes. Fluid flow and distribution within fracture networks may be a significant factor in the ability of microorganisms to degrade VOCs, as they affect the availability of substrate, moisture and nutrients. Biological activity can change liquid surface tension and generate biofilms that may change the wettability of solid surfaces, locally alter fracture permeability and redirect infiltrating liquids. Our approach has four components: (1) establishing a conceptual model for fluid and contaminant distribution in the geologic matrix of interest; (2) physical and numerical experiments of liquid seepage in the fracture plane; (3) nondestructive monitoring of biotransformations on rock surfaces at the micron-scale; and, (4) integration of flow and biological activity in natural rock "geocosms". Geocosms are core-scale flow cells that incorporate some aspects of natural conditions, such as liquid seepage in the fracture plane and moisture content. The experimental work was performed with rock samples and indigenous microorganisms from the site of the United States Department of Energy's Idaho National Engineering and Environmental Laboratory (INEEL), located in a basalt flow basin where VOC contamination threatens the Snake River Aquifer. The insights gained from this approach should contribute to the design of techniques to monitor and stimulate naturally occurring biological activity and control the spread of organic contaminants.
\end{abstract}




\section{Introduction}

Subsurface contamination from volatile organic compounds (VOCs) is ubiquitous due to the widespread production and use of organic solvents and hydrocarbon fuels. At ambient pressures and temperatures in the shallow subsurface, these substances are commonly introduced into the ground as liquids that are immiscible with water; hence they are commonly designated as non-aqueous phase liquids (NAPLs) (Mercer and Cohen, 1990). Many VOC contaminants of concern originate from halogenated organic solvents which have densities greater than water and are referred to as dense NAPLs, or DNAPLs; others, such as petroleum products, may be less dense than water, and are called light NAPLs or LNAPLs.

NAPL contamination in fractured rock aquifers presents a particularly difficult characterization and remediation problem (Kueper and McWhorter, 1991). NAPL migration is likely to be dominated by the highly permeable pathways provided by rock fractures and joints. Relatively small volumes of a NAPL can migrate over large distances, both vertically (due to preferential flow paths through channels within fracture planes) and laterally where vertical fractures intersect horizontal fractures or changing lithology (Roberts et al., 1982; Kueper and McWhorter, 1996). NAPLs may pond at these discontinuities, forming lenses of considerable contaminant mass.

In arid sites with deep water tables, a significant fraction of near-surface NAPL spills may be contained within the vadose zone. At such sites, NAPL fate above the water table may determine the extent of groundwater contamination. Two- and three- phase fluid mixtures may be present within the fractures, including NAPL-gas, water-gas, NAPL-water (in regions of perched water) and NAPL-water-gas. Over time, the NAPL partitions into the surrounding solid, aqueous and vapor phases (Schwille, 1988; Parker et al., 1994). VOC transport in the aqueous and vapor phases produces extensive lateral and vertical spreading of the contaminant beyond the original NAPL distribution (e.g. Conant et al., 1996; Johnson and Kueper, 1996; Mendoza et al., 1996; Seely et al., 1994).

Remediation is impeded by the difficulty of locating the NAPL itself, which through volatilization, dissolution into infiltrating water and potential remobilization provide longterm sources of wider-scale contamination. Significant inventories of VOCs may partition and diffuse into the pore space of the less-accessible matrix rock (Parker et al., 1996), 
where removal by flushing, or vapor extraction is seriously limited by slow diffusion processes.

Biotransformation of VOCs in the vadose zone represents both an attractive enhancement (Hoeppel, et al., 1991) of, and alternative to, vapor extraction. In a wide variety of subsurface environments, in situ bioremediation has been demonstrated to effectively contain the spread of contaminants (including many chlorinated solvents) while converting a significant fraction of their mass to harmless byproducts (National Research Council, 1994). However, the nature and extent of these processes in the vadose zone and/or fractured rock is not well understood. There is some field evidence that biodegradation of chlorinated solvents can occur in fractured rock vadose zone settings (e.g., Conrad et al., 1997), but major questions remain as to how to characterize the extent of naturallyoccurring biological activity and how to stimulate and monitor it for the remediation of contaminated aquifers. While the numbers of indigenous bacteria in the fractured-rock vadose zone in arid regions are low, experiments have indicated that their activity may be stimulated with the addition of water, nutrients and organic carbon (Palumbo et al., 1994).

This paper addresses the processes controlling the fate of NAPL contaminants in a fractured-rock vadose zone. A key aspect of this work is to consider the close coupling between fluid flow dynamics and biotransformation processes. Fluid flow and distribution within fracture networks may be a significant factor in the ability of microorganisms to degrade VOCs, as they affect the availability of substrate, moisture and nutrients. Biological activity can change liquid surface tension and generate biofilms that may change the wettability of solid surfaces, locally alter fracture permeability and redirect infiltrating liquids.

Our overall objective is to provide a scientific basis for field investigations, site characterization, and remedial action for NAPL contamination in fractured rocks. More specifically, we are interested in determining the potential for bioremediation of VOCs in fractured-rock vadose zones in a manner that incorporates the specific geology, water seepage patterns and the indigenous microorganisms at a given site. This paper is organized around the four components of our approach: (1) establishing a conceptual model for fluid and contaminant distribution in the geologic matrix of interest; (2) physical and numerical experiments of liquid seepage in the fracture plane; (3) non-destructive monitoring of biotransformations on rock surfaces at the micron-scale; and (4) integration of flow and biological activity in natural rock "geocosms". Geocosms are core-scale flow cells that incorporate some aspects of natural conditions, such as liquid seepage in the 
fracture plane and moisture content. The experimental work was performed with rock samples and indigenous microorganisms from the site of the United States Department of Energy's (USDOE) Idaho National Engineering and Environmental Laboratory (INEEL), located in a basalt flow basin where VOC contamination threatens the Snake River Aquifer.

\section{Geologic matrix and fluid distribution}

The conceptual model for fluid and contaminant distribution begins with an understanding of the geologic matrix. The INEEL is located in the Eastern Snake River Plain (ESRP) which was formed from sequences of basalt flows. The flows are often bounded by rubble zones and sedimentary interbeds of clay, silt, sand and gravel that may accumulate between flow events. A typical basalt flow can extend over an area of 150 to $300 \mathrm{~km}^{2}$ (Whitehead, 1992), with individual lobes extending $300 \mathrm{~m}$ in length, 30 to $120 \mathrm{~m}$ in width and from 3 to $10 \mathrm{~m}$ thick, overlapping and building on the undulating topography of previous flows (Sorenson et al., 1996; Knutson et al., 1990). Perched water often occurs at the sedimentary interbeds between the basalt flows. Most of the groundwater recharge arises from spring melt of the surrounding mountain snow-pack, part of which is transported across the surface of the ESRP by ephemeral rivers. A comprehensive geologic description of the basalt flows of the ESRP is presented by Whitehead (1992).

The cooling behavior of the basalt flow produces layers of different textures within a given flow unit. The bottom layer is usually fractured and rubbled, and is overlain by a vesicular element, generally fractured into columnar polygons. Above the lower vesicular element is a coarse-grained, massive, generally nonvesicular central element, which comprises about half of the flow thickness, and is generally quite dense with few fractures except for vertical columnar joints. The upper vesicular element typically accounts for about a third of the total flow thickness. This element may have a parting parallel to the upper surface as well as fissures and broken basalt that may contribute to rubble zones in the substratum of the overlying flow (Knutson et al., 1990). The upper portion of the flow unit, or entablature, generally consists of columns of smaller diameter, formed by the rapid convective cooling near the surface, relative to the more widely-spaced columns of the lower portion of the basalt flow, called the colonnade, which formed from slower conductive cooling (Long et al., 1995; Degraff and Aydin, 1993; Degraff et al., 1989). The column bounding fractures of the colonnade and entablature may intersect, may terminate within the rock matrix, or may be connected laterally by column-normal fractures (Long et al., 1995). 
While regional, lateral groundwater transport is controlled by the large-scale layering of multiple basalt flows and rubble zones (Sorensen et al., 1996), processes affecting contaminant fate are controlled by smaller-scale features within a given basalt flow or a vertical sequence of a few layers. The vesicular basalt matrix rock has large storativity, but low hydraulic conductivity, arising from the poorly connected trapped bubbles formed when the basalt cooled. While liquid seepage occurs mostly in the fractures, and through rubble zones, seeping liquids can accumulate and slowly imbibe into the matrix rock where fractures intersect horizontal discontinuities (including perched water) or terminate within the matrix. The lower permeability of the dense basalt implies that most of the fluid phase remains in the fractures. Fracture geometry will also affect NAPL distribution and fate. Core examination from slanted holes at Box Canyon, an uncontaminated site adjacent to the INEEL, revealed vertical fractures with smooth, parallel sides, consistent with cooling cracks. The horizontal fractures frequently have rougher and more non-parallel walls and may intersect vesicles (Long et al., 1995); NAPL trapping in these fractures is likely to be much more significant than in vertical fractures due to their greater roughness and small gravity component for flow.

While the pore space of the vadose zone is only partially saturated with water, several meters below the ground surface the relative humidity $(\mathrm{RH})$ of the air should be close to $100 \%$. This is because it takes extremely high suction pressures (i.e. very dry rock) to reduce water vapor pressure significantly below saturated values. For example, a large number of in situ measurements in the very thick unsaturated zone at Yucca Mountain, Nevada, has shown moisture tension (= suction pressure) in the range of from -0.3 to -0.6 $\mathrm{MPa}$ (Rousseau et al., 1997). At $20^{\circ} \mathrm{C}$, the average temperature in the deep vadose zone, Kelvin equation (e.g. Adamson, 1980) predicts a relative humidity of $99.8 \%$ and $99.6 \%$ for -0.3 and $-0.6 \mathrm{MPa}$, respectively.

Even in the absence of flowing liquid water, the vapor phase may provide enough water to maintain the viability of microorganisms that may become active during seepage events. In air at $100 \% \mathrm{RH}$, vapor condensation can readily occur with small decreases in temperature. Furthermore, osmotic pressure gradients will drive vapor condensation onto a more saline liquid (perhaps microorganisms) at aqueous-gas interfaces. Therefore, liquid water may occur and be available to mircoorganisms in regions not directly contacted by seepage water. 


\section{Isotopic evidence for biodegradation of VOCs in the vadose zone at INEEL}

The potential significance of biological activity in contaminated fractured rock vadose zones is indicated by isotopic evidence from the Radioactive Waste Management Complex (RWMC) at the INEEL, where a major plume of VOCs exists in the vadose zone at (Lodman et al., 1994). Low-level radioactive waste resulting from USDOE activities was deposited in drums in the shallow pits ( $1.5 \mathrm{~m}$ deep) at the RWMC. These drums also contained significant amounts of chlorinated hydrocarbon compounds (e.g., carbon tetrachloride, 1,1,1 trichloroethane, and trichloroethene) mixed with lubricating oils. Vapor samples collected from monitoring wells at the site contain high levels of chloroform, which is an intermediary byproduct of biodegradation of carbon tetrachloride, but was not an original component of the waste.

Based on this evidence of biodegradation of the contaminants, a study of the amounts and carbon isotopic compositions of $\mathrm{CO}_{2}$ in the subsurface was conducted (Conrad et al., 1997). Many biological reactions preferentially utilize the lighter isotopes, causing the isotopic compositions of the substrates and the products to be shifted from their original ratios. $\mathrm{CO}_{2}$ concentrations in gas samples collected from two background wells located approximately $1 \mathrm{~km}$ southeast of the complex ranged from 0.04 to $0.2 \%$ by volume, with the highest concentrations in shallower samples. In the vicinity of the disposal pits, $\mathrm{CO}_{2}$ concentrations were significantly higher (up to $2 \%$ ) in the subsurface. The values of the carbon isotope ratio $\left(\delta^{13} \mathrm{C}\right)$ of the $\mathrm{CO}_{2}$ in the background wells were between $-13 \%$ o and $-21 \%$ and generally decreased with increasing depth. In the complex, the $\delta^{13} \mathrm{C}$ values were somewhat lower, ranging between $-18 \%$ and $-23 \%$, with the lowest values occurring in the samples with the highest $\mathrm{CO}_{2}$ concentrations. The lower $\delta^{13} \mathrm{C}$ values of the enriched $\mathrm{CO}_{2}$ samples suggest a depleted ${ }^{13} \mathrm{C}$ source, such as the chlorinated hydrocarbon compounds or lubricating oil. In the background wells, the radiocarbon concentrations of $\mathrm{CO}_{2}$ were near modern atmospheric concentrations. In the contaminated area, the ${ }^{14} \mathrm{C}$ content of the $\mathrm{CO}_{2}$ ranged from 0 to greater than 100 times modern concentrations. The high ${ }^{14} \mathrm{C} \mathrm{CO}_{2}$ is derived from other radioactive wastes deposited at the RWMC with elevated ${ }^{14} \mathrm{C}$ (cement blocks used to shield nuclear reactors). The $\mathrm{CO}_{2}$ with less than modern levels of ${ }^{14} \mathrm{C}$, however, was undoubtedly a byproduct of biodegradation of hydrocarbon compounds manufactured from fossil fuels (the chlorinated compounds and/or the lubricating oil). 
These data (increased chloroform, increased $\mathrm{CO}_{2}$, shifts in the isotopic compositions of the $\mathrm{CO}_{2}$ ) provide strong evidence that some biodegradation of the contaminants is occurring in the vadose zone at the RWMC. Whether the degradation is occurring in the immediate vicinity of the waste, possibly in an anaerobic pocket beneath the pits, in regions of perched water, or throughout the vadose zone is not evident from the data. It is also not obvious if all the contaminants are being degraded or which degradation pathways (aerobic or anaerobic) are important. Without answering these and other questions, it will be difficult to predict the ability of the natural biological activity to contain the plume or to design a program to enhance bioremediation at the site.

\section{Experimental investigations}

The experiments presented here investigate liquid seepage phenomena in a single fracture and biotransformation processes on natural rock surfaces. The understanding gained from these experiments is then integrated in an experiment of water seepage within a fracture plane in the presence of microorganisms. This link is based upon our hypothesis that liquid distributions and flow patterns within the fracture plane set the stage for potential biotransformations, as they affect the transport of water, nutrients and contaminants to and from microorganisms.

\section{Liquid seepage in fractures}

We first describe flow visualization and tracer experiments of gravity-driven unsaturated flow within a transparent replica of a natural rock fracture that were conducted to identify important flow phenomena and develop conceptual models of liquid seepage in the fracture plane. The results and insights from selected numerical experiments of liquid seepage follow, which illustrate an approach for developing predictive models to extrapolate laboratory observations to the field scale.

Physical experiments. In flow visualization experiments, liquid is introduced to an inclined fracture replica at slightly negative inlet pressures to maintain partially saturated flow. Experiments are conducted for a range of inlet pressures, angles of inclination and liquid properties. Inlet pressures, flow rates and liquid distribution are continuously monitored. These experiments provide a direct correlation between fracture geometry (i.e. aperture distribution), fracture inclination, liquid properties and seepage behavior. Detailed descriptions of the experiments can be found in Su et al. (1998), Geller et al. (1998) and Geller et al. (1997). 
We also perform tracer tests for unsaturated flow to measure the travel time of flowing water through the fracture plane. Travel time is a quantitative measure of preferential flow and an indication of the potential for physical, chemical and biological equilibration between the flowing liquid and the phases it contacts. The interpretation of the tracer breakthrough curves (BTC) is enhanced with flow visualization. This understanding can then be applied to the interpretation of BTCs in natural fractured rock where the liquid distribution cannot be directly observed.

Figure 1 shows the aperture distribution in a $21.5 \mathrm{~cm} \times 33 \mathrm{~cm}$ epoxy (Eccobond 27, W.R. Grace Co., Canyon MA) replica cast from both halves of a natural granite fracture (Su et al., 1999), using a procedure adapted from Gentier (1986) and described by Persoff and Pruess (1995). The aperture distribution of the fracture replica is measured nondestructively from light attenuation through the replica saturated with dyed water (after Persoff and Pruess (1993, 1995), Nicholl et al. (1994), and Glass and Nicholl (1995)). The attenuation of light is a function of the distance the light travels, and is correlated to the width of open space of the fracture by calibration to the intensity of light transmitted through known apertures filled with the same liquids.

The surface properties of the epoxy replica are important in interpreting the results of the following seepage experiments. Water is intermediately wetting to epoxy (contact angle ranges from $57^{\circ}$ to $65^{\circ}$, Geller et al, (1996)), which sómewhat reduces capillary forces and trapping of the non-wetting phase compared to strongly water-wet systems. Most common aquifer minerals, such as quartz, carbonates and sulfates, are strongly water-wet (Demond and Lindner, 1993); however, natural hydrophobic organic materials and anthropogenic organic compounds on the mineral surface may create conditions of neutral wettability. Powers et al. (1996) found that a wide range of wetting conditions results from the exposure of sands to complex organic liquid contaminant mixtures. Geller et al. (1996) measured a $57^{\circ}$ contact angle for water on a smooth, clean granite surface. This is much closer to the contact angle of water on epoxy, than on glass, which is commonly used as an analog for natural rock surfaces (Nicholl et al., 1994). Geller et al. (1996) also observed that a water drop on the fracture surface of the same rock sample spread spontaneously, illustrating the important role that near-surface porosity and small-scale roughness of a natural fracture surface may have on wetting behavior. An additional consideration in the use of the transparent replicas is that they are non-porous and therefore do not incorporate matrix interaction. Some degree of matrix interaction can be obtained with flow visualization by using one half of the rock fracture mated to a transparent replica of the 
second half, which is used in the integrated experiment described towards the end of this paper.

Figure 2 describes the experimental arrangement for liquid delivery to the fracture, either with constant-head (Mariotte bottle) or constant flow (syringe pump) inlet conditions. Water seepage patterns in the replica for constant head inlet conditions are shown in Figure 3. In this experiment, the replica was inclined at $70^{\circ}$ from the horizontal, with $-3.5 \mathrm{~cm}$ $\mathrm{H}_{2} \mathrm{O}$ tension maintained at the inlet. The seepage pattern corresponds to the measured aperture distribution in Figure 1, with water spreading transverse to the flow direction in the tightest aperture regions, forming "capillary islands", while narrow channels form in the larger aperture regions. Water flows in one or two narrow channels that undergo cycles of snapping and reforming, even though pressure is maintained constant at the inlet. This cycle is shown in the enlarged red boxed region. Intermittent flow occurs for a large range of flow conditions, surface properties and angles of fracture inclination. Su et al. (1999) presents a detailed laboratory investigation of intermittent flow as a function of fracture aperture distribution, boundary conditions and fracture inclination. We have observed intermittent flow in rock-replica combinations, where a natural rock fracture is mated to a replica of the second half, and in fracture models constructed of parallel glass-plates (Su et al., 1999, Geller et al., 1996; 1997). Under field conditions, unsteady seepage will arise from the episodic nature of recharge events.

Tracer breakthrough curves are shown in Figure 4(a) and (b), for a flow rate of $5 \mathrm{~mL} / \mathrm{hr}$ at a fracture inclination $(\phi)$ of $81^{\circ}$ from the horizontal. The change in the electrical conductance of the liquid, which is directly proportional to tracer concentration, is measured with two pairs of gold wire electrodes embedded in the fracture inlet and outlet for a step input of an electrolyte tracer $\left(4.5 \times 10^{-3} \mathrm{M} \mathrm{CaCl}_{2}\right)$. The results are plotted in terms of the measured concentration $\mathrm{C}$, normalized by the concentration of the introduced tracer $\mathrm{C}_{\mathrm{o}}$. Direct observation showed that the fluctuations in the outlet breakthrough curve (Figure $4 \mathrm{~b}$ ) correspond to intermittent flow behavior. Figure 4(c) plots the travel times from tracer tests at three different angles of inclination and for flow rates of 3 and $5 \mathrm{~mL} / \mathrm{hr}$ as a function of gravity force (proportional to $\sin \phi$ ). The travel time is calculated from the difference of the fracture outlet and inlet tracer breakthrough times at $C / C_{0}=0.5$. The measured increase in travel time at higher angles seems counter-intuitive, but information from flow visualization provides an interpretation of this result. Visual observation showed that the frequency of channel snapping increases at higher angles of inclination, suggesting that flow intermittency increases liquid hold-up in the fracture. 
The seepage of liquids of varying physical and chemical properties in an initially dry fracture exhibit subtle differences in behavior. This is shown in Figure 5, which compares the liquid distribution following seepage into the initially dry fracture replica for water and two NAPLs: n-dodecane and PCE. These liquids represent a range of density and viscosity contrasts relative to water (Table 1). While the liquid distributions are similar, the frequency at which the narrow channel below the wide capillary island snaps and reforms is approximately five times greater for the NAPLs than for water. This is explained by the increased lateral spreading of the NAPLs which have zero contact angle on the epoxy, compared to the reduced spreading of water. The lateral spreading of the NAPL removes more mass from the flowing channel, which in turn increases the rate at which it thins and subsequently snaps.

In contrast to the behavior of a single liquid phase, the seepage of a NAPL into a fracture with residual water gives rise to even more complex fluid distributions. Figure 6 shows the liquid distribution after $\mathrm{n}$-dodecane (red) was introduced into a fracture having residual water (blue) saturation. The NAPL flows along solid/water/air contact lines and is also diverted by the presence of residual water to dry parts of the fracture, resulting in a more disperse distribution than in an initially dry fracture. NAPL trapping occurs both along the water-air interface and in the previously dry parts of the fracture. Observation of subsequent water infiltration further complicates the distribution of liquid-liquid-vapor interfaces due to additional water-trapping along NAṔ̀-air interfaces.

Numerical Simulations. Predictive modeling is needed to extrapolate observed laboratory flow and transport behavior to the field scale. As permeability distributions within a fracture are poorly known in the field, these attributes are stochastically generated in the numerical simulations. The simulated flow behavior is qualitatively compared with results from physical experiments to determine which features of permeability distributions best represent observed physical behavior. As in physical experiments, the results of numerical experiments can reveal behavior and trends that are not intuitively apparent.

For purposes of theoretical analysis, "small-aperture" fractures in hard rocks of low matrix permeability, such as granites, welded tuffs and basalts, have been conceptualized as twodimensional heterogeneous porous media (Pruess and Tsang, 1990). Multiphase flow in such fractures has been modeled with macroscale continuum concepts, such as a multiphase extension of Darcy's law that includes relative permeability and capillary pressure effects (Pruess, 1998). Laboratory experiments have shown that those concepts are applicable on a scale of 0.1 to $1 \mathrm{~m}$ or larger (Persoff and Pruess, 1995). 
The key to realistic modeling of multiphase flow in heterogeneous fractures is a realistic representation of the permeability structure in the fracture plane. Aspects of fracture aperture distribution that are believed to be essential for replicating natural features include (a) the presence of asperity contacts, where the fracture walls touch, (b) a more or less gradual change towards larger apertures away from the asperities, (c) small-scale fracture wall roughness, and (d) finite-size spatial correlation length among apertures (Wang and Narasimhan, 1985; Pruess and Antunez, 1995).

Different methods have been used to synthetically generate spatially-correlated fracture aperture distributions with realistic features. These include the "turning bands method" as implemented by Tompson (1989), and simulated annealing with a modified version of the "Metropolis algorithm" (Metropolis et al., 1953; Liou et al., 1998). The turning bands method is limited to an underlying log-normal distribution of fracture apertures (or permeabilities), while simulated annealing has the flexibility to deal with arbitrary distributions. Figure 7 shows examples of synthetic permeability distributions in the fracture plane. These were generated by simulated annealing with the standard Metropolis algorithm (a), as well as with a modified version (b) that employs a concept of "neighborhood" to force asperity contacts (regions of zero fracture permeability) to coalesce into simply-connected regions; see Liou et al. (1998) for more details.

Our general-purpose multiphase flow simulator TOUGH2 was employed to explore unsaturated water seepage in synthetic heterogeneous fractures. For the applications presented here, liquid flow in variably saturated heterogeneous media was modeled by Richards' equation (1931),

$$
\frac{\partial}{\partial t} \theta=\operatorname{div}[K \nabla h]
$$

where $t$ is time, $\theta$ is specific volumetric moisture content, $\mathrm{K}$ is hydraulic conductivity, and $\mathrm{h}$ is hydraulic head. Figure 8 shows simulated seepage patterns in the fractures of Figure 7 for uniform infiltration of water at the top boundary. In agreement with the laboratory experiments described above, and with field observations in thick unsaturated fracture zones (Pruess, 1998b), flow was found to generally proceed in dendritic patterns along fast preferential paths, giving rise to such features as localized ponding and bypassing. However, our simulations have not provided any evidence for flow intermittency which is so prominent in the laboratory experiments. This may indicate limitations of the continuum approach used, and is being further investigated. 
Additional simulation studies (not shown) have been carried out to demonstrate the crucial role of "funneling" structures (Kung, 1990a, b) for generating fast preferential flow. Such geometric structures on different spatial scales can be provided by low-permeability obstacles, such as asperity contacts in fractures and fracture terminations (Figure 9). As would be expected, the simulations show that for increasing length of sub-horizontal obstacles, flow funneling effects become stronger, and seepage velocities increase (Pruess, 1998b). At the same time, average vertical permeability decreases when more spatially extensive obstacles are present. Thus we have the seemingly paradoxical result that vertical advancement of liquid seeps in unsaturated fractures may actually be faster for media of lower average permeability.

For containment and remediation of contaminants in fractured rock it is often necessary to evaluate flow and transport processes over space and time scales that are considerably larger than can be realized through laboratory experimentation. We have analyzed the behavior of Eq. (1) under simultaneous space and time scaling

$$
\begin{aligned}
& t \rightarrow t^{\prime}=\lambda_{t} \cdot t \\
& x \rightarrow x^{\prime}=\lambda_{x} \cdot x \\
& z \rightarrow z^{\prime}=\lambda_{z} \cdot z
\end{aligned}
$$

where $\mathrm{x}$ and $\mathrm{z}$ are horizontal and vertical coordinates, respectively, in the fracture plane and $\lambda_{t}, \lambda_{x}$ and $\lambda_{z}$ are scaling factors for time, and horizontal and vertical length, respectively. For gravity-driven seepage in highly permeable fractures an approximate invariance was found to hold when

$$
\lambda_{\mathrm{x}}{ }^{2}=\lambda_{\mathrm{z}}=\lambda_{\mathrm{t}}
$$

Eq. (3) is applicable to media with self-affine heterogeneity structure, where the heterogeneous permeability fields scale by factors $\lambda_{x}$ and $\lambda_{z}=\lambda_{x}{ }^{2}$. It suggests that seepage patterns should remain approximately invariant when vertical scale and time scale are stretched by the square of horizontal stretching. The approximate validity of Eq. (3) was demonstrated through numerical simulation experiments and through an analysis of the competition between gravity and capillary-driven flow (Pruess, 1998a). Many naturally occurring geometries are self-similar or self-affine fractals (Mandelbrot, 1983), and rock fractures may also have such properties (Brown and Scholz, 1985; Wang et al., 1988; Nolte et al., 1989). Eq. (3) is applicable to heterogeneous fractures on different scales that 
represent different realizations of the same or a similar heterogeneity structure. The scaling behavior given by Eqs. $(2,3)$ suggests that, in fractured media with "sufficiently" high permeability, transient seeps should show a more vertically elongated appearance as the scale of observation increases.

These numerical results demonstrate an approach to upscaling laboratory observations to the field. However, a mechanistic description of biological processes under conditions of preferential flow in fractures is required to incorporate biotransformation into such simulations. Our approach to obtaining this data is described in the following section.

Biotransformation of volatile organic contaminants in naturally fractured rock

Laboratory characterization of biotransformation processes in a manner that represents natural field conditions is a major challenge. The activity of microorganisms attached to a solid differs greatly from planktonic microorganisms, in terms of their resistance to toxic chemicals and the transport of contaminants and nutrients to the microorganism. This is in part due to the production of exopolysaccharides (EPS) upon attachment, and formation of "organized communities" or biofilms (Marshall, 1985). This limits the relevance of traditional batch reactor tests of suspended media in determining the potential for biotransformation of contaminants. Prevailing subsurface conditions of constant near $100 \% \mathrm{RH}$ are difficult to replicate in the laboratory. Another challenge is the study of reactions at the dilute environmental concentrations of microorganisms and chemical species that occur in the fractured rock vadose zone.

Significant issues arise in obtaining samples of indigenous microorganisms associated with subsurface geologic materials. We acquired core samples from the vadose zone at the Test Area North (TAN) site at INEEL within the context of the Department of Energy's Subsurface Science Program. These samples were obtained according to the protocol developed by Colwell et al. (1992), whereby the extent of contamination of non-indigenous microorganisms is determined, and an undisturbed "defensible" sample can be sub-sampled from the core. Drilling fluid is expected to contact fracture surfaces during sampling, and therefore defensible samples of fractures themselves cannot be obtained. The samples were acquired within a ten-foot interval above the current groundwater table, where aqueous concentrations of trichloroethylene were on the order of $1 \mathrm{ppm}$. In this location, it was hoped that the indigenous microorganisms had acclimated to the presence of organic contamination. 
Our approach, based on the above considerations, is to characterize indigenous microorganisms and evaluate the potential for contaminant degradation on defensible samples in micro-scale experiments. Then, column-scale studies, termed "geocosms", are conducted on sterilized basalt rock inoculated with culturable organisms extracted from the defensible samples. In geocosms, we consider the mass transfer limitations to biological activity arising from fluid distribution. The experimental work described in the following two sections lays the groundwork for studies involving actual contaminant degradation.

Micro-scale experiments: We have developed and applied two innovative techniques at Lawrence Berkeley National Laboratory's Advanced Light Source Facility to monitor the space and time-resolved biological activity and chemical transformations on mineral surfaces. These measurements provide a ten-micron spatial resolution of bacterial, mineral and contaminant distribution on the surfaces of natural and treated geologic media, and have provided mechanistic insights regarding biological activity on mineral surfaces.

In the first technique (Holman et al., 1998a), surface-enhanced infrared reflectanceabsorption (SEIRA) microspectroscopy was applied to qualitatively monitor the in situ localization of microorganisms on mineral surfaces and relate the distribution to the microstructure and mineral composition of the rocks. A photograph of a section of the "defensible" intact basalt core obtained from INEEL is shown in Figure 10(a). It is an iron-magnesium-rich rock, consisting mainly of calcić plagioclase feldspar, pyroxene and olivine. Vesicles occupy about $10-25 \%$ of the bulk volume. Some vesicles have secondary mineral coatings. Cores such as these were sliced aseptically by a specially modified tool from which sub-samples for micro-scale studies were selected. Figure 10(b) is a photo micrograph of the $400 \mu \mathrm{m} \times 500 \mu \mathrm{m}$ area used in this study.

Six isolates were identified from cultivable colonies sampled from the vesicle surfaces of the defensible samples using fatty acid methyl ester (FAME) analysis. Two isolates were Gram-negative (Pseudomonas putida, and $P$ seudomonas fluorescens) and four were Gram-positive (Arthrobacter oxydana, Bacillus atrosepticus, Micrococcus lylae, and Nocardia globerula). Similar bacteria have been found in other terrestrial deep subsurface environments (Amy, 1997; Balkwill and Boone, 1997; Zheng and Kellogg, 1994; Haldeman et al., 1993). From the absorption intensity spectra of these isolates, we identified two absorption peaks as "biomarkers" for mapping the distribution of bacteria and changes in their level of activity; the microbial protein Amide I with an absorption peak at $1650 \mathrm{~cm}^{-1}$ wave number, and the protein Amide II at the $1550 \mathrm{~cm}^{-1}$ wave number. The 
absorption bands for the biomarkers are distinct from the absorption bands due to the presence of silicate minerals, which occur within the 1300 to $800 \mathrm{~cm}^{-1}$ region.

Areal contour maps of the absorption peak heights over different absorption bands were derived from measurements with a Fourier Transform Infrared (FTIR) spectrometer through a $10 \mathrm{~mm} \times 10 \mathrm{~mm}$ aperture with a computer-controlled $\mathrm{x}-\mathrm{y}$ mapping stage. Figure 11 (a) is a contour plot of the relative absorption intensity in the 1300 to $800 \mathrm{~cm}^{-1}$ region for silicate minerals. Zero values coincide with the vesicles indicated in Figure 10 (b), and values greater than zero indicate relative concentrations of silicate minerals. Figure 11 (b) shows the contour plot of the absorption intensity at $1650 \mathrm{~cm}^{-1}$; the Amide I biomarker coincides with the dark areas that represent vesicles in Fig 10 (b) and 11 (a), indicating that bacteria are associated with the vesicle surfaces. The high absorption intensity contours extend somewhat beyond the vesicle wall, suggesting that bacteria may have bored into the rock matrix from the vesicle surface.

The SEIRA results are consistent with confocal laser scanning microscopy obtained from the same sample before SEIRA was performed. Figure 12 shows the distribution of microbial colonies along the edge of the central vesicle in the study area, observed with simultaneous excitation at 488 and $514 \mathrm{~nm}$. The scans at different focal lengths indicate that most of the microbial colonies extend less than $1 \mu \mathrm{m}$ from the basalt surface. Independent measurements showed that the above-mentioned isolates fluoresced naturally at these wavelengths.

Higher resolution scanning was conducted through the bacteria colony clusters along the axis BB', denoted in Figures 12(b) and 10. Regions A through B in Figure 13 show a decline in biomarker peaks, which disappear abruptly at the transition into the bacteria-free area indicated by region $\mathrm{C}$ (scan number 24). These scans are more sensitive to the presence of bacteria compared to the confocal laser scanning microscopy, indicating that not all the indigenous bacteria fluoresce at 488 and 514 wavelengths, and that other species in addition to those isolated are present. Dramatic changes in the spectra within the silicate mineral absorption band $\left(1300\right.$ to $\left.800 \mathrm{~cm}^{-1}\right)$, indicated in regions $\mathrm{D}$ through $\mathrm{F}$, show that the decline in biomarker peaks corresponds to a change in mineralogy. Specifically, the sharp spectral features in region $F$ are associated with the appearance of calcic plagioclase feldspar, suggesting that bacteria do not attach to this mineral.

The second mapping technique involved the use of a synchrotron infrared beam to nondestructively measure the change in microbial activity on the basalt surface in response to 
changes in relative humidity (RH). Toluene degradation by Arthrobacter oxydans, isolated from the defensible samples was monitored at $100 \%$, then at $25 \% \mathrm{RH}$. These large contrasts in RH values compare conditions at depth with conditions that represent nearsurface desert soils. Small RH changes of less than $1 \%$ have been shown to significantly affect biofilm morphology and toluene utilization (Holden et al., 1997). Toluene was chosen for this first experiment because it is known to be readily degradable and has stable, known metabolites. The results are plotted in terms of the relative intensity peaks for the biomarker protein Amide I, toluene, and its early metabolites benzyl alcohol and catechol, over the surface area of the rock sample. Figure 14 shows the abundance of these compounds after five days of exposing the rock sample to $90 \mathrm{ppm}$ toluene vapor at $100 \%$ $\mathrm{RH}$. The location of the highest peaks of the biomarker coincides with the toluene and metabolite peaks, implying that toluene sorbed to the bacteria cells. Figure 15 shows the relative peak intensities after the same specimen was exposed to toluene vapor at $25 \% \mathrm{RH}$ for five days. The large decrease in biomarker peaks relative to the conditions of $100 \% \mathrm{RH}$ is accompanied by a decrease in presumably sorbed toluene, which may indicate a significant decrease in biomass at the lower $\mathrm{RH}$ conditions.

In a separate, complementary experiment, we observed that the same bacteria exposed to $23 \% \mathrm{RH}$ air can be revived when the ambient air humidity is returned to $100 \% \mathrm{RH}$ (Holman et al., 1997). The bacteria were incubated on an aluminized microscope slide that was coated with a thin film of basalt extract and monitored with FTIR while changing the relative humidity from $100 \%$ to $23 \%$ and back to $100 \%$. The spectra in Figure 16 show the biomarker peaks decreased significantly after 7 days exposure to $23 \% \mathrm{RH}$ air, and began to increase after 6 hours of exposure to $100 \% \mathrm{RH}$ air.

Geocosm experiments. Coupling between fluid flow and microbial activity arises from the likelihood that biological growth occurs in the path of the seepage water, and may alter the transport properties of the rock due to blockage or change in solid surface properties by biofilm formation and change in liquid surface tension. The presence of residual NAPL will further alter the patterns of microbial activity and subsequent water seepage.

In "open" geocosm experiments, we introduce water into a fracture that is assembled from one piece of wall rock, mated to the transparent epoxy replica of the second side of the fracture. These experiments incorporate some aspects of natural conditions, while providing direct visual observation of flow dynamics. In the experiment reported here, the rock was a natural fracture in dense basalt from an outcrop at Box Canyon, an 
uncontaminated site adjacent to the INEEL. The replica and rock were sterilized, then the rock fracture surface was sprayed with a mixed culture of microorganisms derived from the defensible samples to an estimated coverage of $7 \times 10^{7}$ cells $/ \mathrm{cm}^{2}$.

The rock-replica assembly, inclined at $20^{\circ}$ from the horizontal, was enclosed in a box with a glass cover, in which ambient air was maintained at $100 \%$ relative humidity (Figure 17). Seepage water was obtained from a rock extract solution, in order to reproduce the chemical composition of infiltrating water that equilibrates with the host rock during percolation. Chemical analysis showed that major nutrients in the rock-extract water included nitrate, magnesium, iron, potassium and sulfate; no phosphate was detected. To ensure that we would observe the effects of biological activity on flow in this first experiment, readily degradable glucose was added at a concentration of $10 \mathrm{mg} / \mathrm{L}$ as a carbon source. The rock extract with the glucose had approximately $130 \mathrm{mg} / \mathrm{L}$ non-volatile organic carbon (BC Laboratories, 1998). Fluorescein $\left(\mathrm{C}_{20} \mathrm{H}_{10} \mathrm{O}_{5} \mathrm{Na}_{2}\right)$ was added to the water at $200 \mathrm{mg} / \mathrm{L}$ to permit flow visualization by illumination with near-UV light, which may or may not have been an available carbon source. The seepage water was sterilized by passing it through a sterile $0.2 \mu \mathrm{m}$ filter. A syringe pump delivered the solution at a constant flow rate of $0.33 \mathrm{~mL} / \mathrm{hr}$. Strips of glass-fiber filter paper were placed along the top and bottom of the fracture for liquid distribution and collection. Effluent was collected below the fracture outlet and was periodically extractèd by syringe for sample analysis.

Indicators of biological activity within the fracture during seepage included an increase in the counts of colony forming units (CFUs) in the effluent, and changes in surface tension and total dissolved solids of the effluent water compared to the influent water, and changes in seepage patterns over time. The fracture effluent was analyzed for bacteria counts by plating onto soil-rock extract agar.

Mass balance of the water delivered to the fracture and collected in the effluent indicated no measurable absorption of water into the dense basalt matrix. Effluent counts were on the order of $10^{7}$ to $10^{8}$, with an increasing trend during the experiment that appears to be inversely correlated with the surface tension of the effluent (Figure 18). The agar plates showed the presence of a mixed culture, including organisms with a tendency to spread and of varied pigmentation. Identification of half of the 20 isolates from this experiment using fatty acid methylester (FAME) analysis showed that these were the same microorganisms identified in the core sample isolates from which the mixed culture was obtained. Effluent surface tension generally decreased over time, from initial values of 75 dynes/cm to 55 
dynes $/ \mathrm{cm}$. The effluent $\mathrm{pH}$ values ranged from 7.3 to 8.3 , exhibiting no clear trend with time, and electric conductivity of the effluent was about $50 \%$ greater than the influent, also showing no clear trend with time.

Seepage patterns shown in Figure 19 exhibit features observed in the replica studies and theoretical modeling described earlier, such as channelized flow and capillary islands connected by thin rivulets. The flow channel was initially a single rivulet that extended along the length of the fracture and periodically snapped near the bottom of the fracture plane (Figure 19a). After one week, a capillary island formed in the channel path about one third the way down the fracture plane (Figure 19b). This residual most likely formed from condensed water vapor that migrated into the flow channel from the edges of the fracture. One week later, the fracture surface area covered by liquid residual increased (Figure 19c). Since surface tension decreased and CFUs increased during this time (Figure 18), the increased liquid saturation may be a result of biological activity. The presence of capillary islands in the path of the flow channel had a significant effect on flow behavior. Cycles of filling and partial drainage of each capillary island into the downstream island prevented the formation of a continuous, connected flow channel.

\section{Summary and Conclusions}

Deep fractured rock vadose zones in arid regions have.been thought of as not biologically active, due to dry conditions and minimal organic matter (Palumbo et al., 1994).

However, bacteria are ubiquitous and have been found in such environments, albeit in low numbers (Palumbo et al., 1994; Colwell, 1989). Physical and numerical experiments indicate that water seepage in a fractured rock vadose zone is localized and intermittent. None-the-less, adequate water to maintain the viability of bacteria is likely to exist in the vadose zone because relative humidity will be near $100 \%$. In addition, due to the layered structure of basalt flows, perched water can occur at sedimentary interbeds, with water flowing through fractures and rubble zones and imbibing into the high-storativity vesicular basalt.

Our studies have shown that a mixed culture of viable bacteria exists on the vesicle surfaces of defensible samples. This observation supports the existence of bacteria on fracture surfaces, even though defensible fracture samples cannot be obtained for confirmation. We hypothesize that the activity of these bacteria can be stimulated by contact with liquid water and organic contaminants. We further hypothesize that this activity will not only be 
localized along active seepage pathways, but will also occur in the presence of vapor-phase organic contaminants and water-saturated air.

NAPL organic contaminants migrate through the most permeable pathways, which in the case of the fractured basalt vadose zone are the fractures within the basalt flows and rubble zones between flows. The NAPL will pond at vertical discontinuities and the presence of residual water may redirect the NAPL to areas not contacted by the flowing water. However, much of the rock mass may be exposed to contamination due to the transfer of volatile and soluble organic compounds from the NAPL to the aqueous, vapor and solid phases, whereupon biological degradation of the organic contaminant may be a significant process in controlling its further migration.

Evaluating the biological activity in such systems and identifying the controlling factors requires innovative laboratory studies that extend beyond traditional batch experiments. The development of high-resolution spectroscopic techniques to map bacteria, mineral and contaminant distributions provides potential for non-destructive monitoring of biological activity at the micro-scale . Larger-scale experiments can investigate the role of liquid seepage and distribution on biological activity.

We are currently applying this approach to test the effect of various environmental factors on biotransformation rates and to quantify potential ișotopic shifts caused by biodegradation by measuring the abundance and stable isotopic composition of residual contaminants and of potential metabolic byproducts (e.g., $\mathrm{CO}_{2}$ ). Quantifying any potential isotopic shifts caused by biodegradation of the contaminants is critical for developing the use of isotopic measurements for field monitoring and verification of bioremediation. The insights gained from this work should allow the design of techniques to monitor and stimulate naturally occurring biological activity and control the spread of organic contaminants. 


\section{Acknowledgment}

This work was supported by the Director, Office of Energy Research, Office of Health and Environmental Sciences, Biological and Environmental Research Program, of the U.S. Department of Energy under Contract No. DE-AC03-76SF00098. We gratefully acknowledge Rick Colwell and Kirk Dooley of the INEEL for sample acquisition; Tamas Torok of the Center of Environmental Biotechnology (CEB) at LBNL for guidance and support in the microbiological work; and Terry Hazen and George Moridis of the Earth Sciences Division (ESD) at LBNL for their review of this manuscript. Michael Martin, Wayne McKinney, Carol Hirschmugl of the Advanced Light Source at LBNL and Dale Perry of ESD collaborated in the FTIR development and Denise Schischnes and Steve Ruzin of the Center for Biological Imaging at University of California, Berkeley provided access and support for the confocal microscopy work. 


\section{References}

Adamson, A. W., Physical Chemistry of Surfaces, $4^{\text {th }}$ edition, John Wiley \& Sons, New York, 664 pp., 1980.

Amy, P. S., Microbial dormancy and survival in the subsurface, In, The Microbiology of the Terrestrial Deep Subsurface, P. S. Amy and D. L. Haldeman (Eds.), 185-204, CRC, Lewis Publishers, N.Y., 1997.

Balkwill, D. L. and D. R. Boone, Identify and diversity of microorganisms cultured from subsurface environments, In, The Microbiology of the Terrestrial Deep Subsurface, P. S. Amy and D. L. Haldeman (Eds.), 105-118, CRC, Lewis Publishers, N.Y., 1997.

BC Laboratories, COC\#980101, Laboratory No. 98-00153-1, Bakersfield, CA 1998.

Brown, S. R. and C. H. Scholz. Broad Bandwidth Study of the Topography of Natural Rock Surfaces, J. Geophy. Res.. 90, 12,575-12,582, 1985.

Colwell, F.S., G. J. Stormberg, T. J. Phelps, S.A. Birnbaum, J. Mckinley, S.A. Rawson, C. Veverka, S. Goodwin, P.E. Long, B.F. Russell, T. Garland, D. Thompson, P. Skinner, and S. Grover, Innovative techniques for collection of saturated and unsaturated subsurface basalts and sediments for microbiological characterization. J. of Microbiological Methods, 15:279-292, 1992.

Conant, B. H., R. W. Gillham, C. A. Mendoza, Vapor transport of trichloroethylene in the unsaturated zone: Field and numerical modeling investigations, Water Resour. Res., 32(1), 9-22, 1996.

Conrad, M.E., D.J. DePaolo, B.M. Kennedy, and E.C. Miller, 1997, Carbon isotope evidence for degradation of mixed contaminants in the vadose zone: Geol. Soc. Am., Abst. with Prog. 26, no. 6, A186.

Costerson, J. W., Overview of microbial biofilms, J. Ind. Microbiol., Vol. 15, 137-140, 1995.

Demond, A. H. and Lindner A. S., Estimation of interfacial tension between organic liquids and water, Environmental Science \& Technology, Vol. 27, No. 12, 23182331, 1993.

Geller, J. T., G. Su, H-Y. Holman, M. Conrad, K. Pruess and J. C. Hunter-Cevera, Processes Controlling the Migration and Biodegradation of Non-aqueous Phase Liquids (NAPLs) within Fractured Rocks in the Vadose Zone. FY97 Annual Report, LBNL Report 41387, February, 1998.

Geller J. T., G. Su, H.-Y. N. Holman, M. Conrad, K. Pruess, and J. C. Hunter-Cevera, Processes controlling the migration and biodegradation of non-aqueous phase liquids (NAPLs) in the vadose zone: FY96 Annual Report. LBNL-39996, UC-400, 1997.

Geller, J. T., G. Su and K. Pruess, Preliminary Studies of Water Seepage through RoughWalled Fractures, LBNL Report 38810, July, 1996. 
Gentier, S., Morphologie et comportement hydroméchanique d'une fracture naturelle dans un granite sous constrainte normale, Ph.D. Thesis, Univ. D' Orléans, France, 1986.

Glass, R. J. and M. J. Nicholl, Quantitative visualization of entrapped phase dissolution within a horizontal flowing fracture, Geophysical Research Letters, vol. 22 no. 11, 1413-1416, 1995.

Haldeman, D. L., P. S. Amy, D. Ringelberg and D. White, Characterizationof the microbiology within a $21 \mathrm{~m}^{3}$ section of rock from the deep subsurface, Microb. Ecol., vol. 26, 145-159, 1993.

Holden, P.A., J. R. Hunt and M. K. Firestone, Toluene diffusion and reaction to unsaturated $P$ seudomonas putida biofilms, Biotechnology and Bioengineering, vol. 56, no. 6, 656-670, 1997.

Holman, H.-Y. N., D.L. Perry, and J.C. Hunter-Cevera, Use of infrared microspectroscopy to assess effects of relative humidity on microbial population and their activity in fractured rocks, Gordon Conference on Applied Environmental Microbiology, August 17-22, 1997.

Holman, H.-Y. N., Perry, D.L., and J.C. Hunter-Cevera. Surface-enhanced infrared absorption-reflectance (SEIRA) microspectroscopy for bacteria localization on geologic material surfaces. J. Microbiol. Methods, in press, 1998a.

Holman, H.-Y. N., Perry, D.L., Martin, M.C., and W.R. McKinney. Applications of synchrotron infrared microspectroscopy to the 'study of inorganic-organic interactions at the bacterial-mineral interface, Application of Synchrotron Radiation Techniques to Materials Sciences, MRS Symp. Series, vol. 54, in press, $1998 \mathrm{~b}$.

Hoeppel, R. E., R. E. Hinchee, M. F. Arthur, Bioventing soils contaminated with

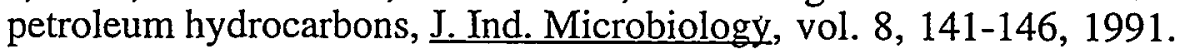

Johnson, R. L. and B. H. Kueper, Experimental studies of the movement of chlorinated solvent compounds and other DNAPLs in the vadose, capillary, and groundwater zones, in Dense Chlorinated Solvents and other DNAPLs in Groundwater: History, Behavior and Remediation, J. F. Pankow and J. A. Cherry, eds., Waterloo Press, 145-178, 1996.

Knutson, C. F., K. A. McCormick, R. P. Smith, W. R. Hackett, J. P. O'Brien and J.C. Crocker, FY89 Report: RWMC Vadose Zone Basalt Characterization, Informal Report EGG-WM-8949, 1990.

Kueper, B. H. and D. B. McWhorter, The behavior of dense, nonaqueous phase liquids in fractured clay and rock, Ground Water, vol. 29, no. 5, 716-728, 1991.

Kueper, B. H. and D. B. McWhorter, Physics governing the migration of dense nonaqueous phase liquids (DNAPLs) in fractured media, in Dense Chlorinated 
Solvents and other DNAPLs in Groundwater: History, Behavior and Remediation, J. F. Pankow and J. A. Cherry, eds., Waterloo Press, 337-353, 1996.

Kung, K. J. S. Preferential Flow in a Sandy Vadose Zone: 1. Field Observation, Geoderma, Vol. 46, pp. 51-58, 1990a.

Kung, K. J. S. Preferential Flow in a Sandy Vadose Zone: 2. Mechanism and Implications, Geoderma, Vol. 46, pp. 59-71, $1990 \mathrm{~b}$.

Liou, T.S., K. Pruess and Y. Rubin. Numerical Simulation Experiments on Water Seepage in Unsaturated, Heterogeneous Fractures, in: K. Pruess (ed.), Proceedings of the TOUGH Workshop '98, pp. 198 - 204, Lawrence Berkeley National Laboratory Report LBNL-41995, Berkeley, CA, May 1998.

Lodman, D., S. Dunstan, W. Downs, J. Sondrup, D. Miyasaki, K. Galloway, K. Izbicki, Treatability Study Report for the Organic Contamination in the Vadose Zone, OU 708, EGG-ER-11121, Idaho National Engineering Laboratory, EG\&G Idaho, Inc., Idaho Falls, Idaho, May 1994.

Long, J.C.S., C. Doughty, B. Faybishenko, A. Aydin, B. Freifeld, K. A. Grossenbacher, P. Holland, J. Horsman, J. S. Jacobsen, T. M. Johnson, K. H. Lee, J. Lore, K. Nihei, J. E. Peterson, Jr., R. Salve, J. B. Sisson, B. Thapa, D. Vasco, K. H. Williams, T. R. Wood, P. Zawislanski, Analog Site for Fractured Rock Characterization, Annual Report FY1995, LBL-38095, UC-600, Lawrence Berkeley National Laboratory, Berkeley, CA. 94720, 142 pp., 1995.

Mackay, D. and Shin, W-Y., The aqueous solubility and air-water exchange characteristics of hydrocarbons under environmental conditions., in Chemistry and Physics of Aqueous Gas Solutions, American Society Testing Materials, Philadelphia, PA., 104-108, 1974.

Mandelbrot, B. B. The Fractal Geometry of Nature, W.H. Freeman and Co., New York, NY 1983.

Marshall, K. C., Mechanisms of bacterial adhesion at solid-water interface, in Bacterial Adhesion, Savage, D. C. and Fletcher, M. (eds.) 133-161, Plenum Press, New York, 1985.

Mendoza, C. A., R. L. Johnson and R. W. Gillham, Vapor migration in the vadose zone, in Dense Chlorinated Solvents and other DNAPLs in Groundwater: History, Behavior and Remediation, J. F. Pankow and J. A. Cherry, eds., Waterloo Press, 179-201, 1996.

Mercer, J. W. and R. M. Cohen, A review of immiscible fluids in the subsurface: properties, models, characterization and remediation, J. of Contam. Hydrol., vol.' 6, 107-163, 1990.

Metropolis, N., A. Rosenbluth, M. Rosenbluth, A. Teller and M. Teller. Equations of State Calculations by Fast Computing Machines, J. Chem Phys. Vol. 21, pp. 1087 1092, 1953. 
National Research Council, Alternatives for Ground Water Cleanup, National Academy Press, Washington, D.C., 1994.

Nicholl, M. J., R. J. Glass, and S. W. Wheatcraft, Gravity-driven infiltration instability in initially dry nonhorizontal fractures, Water Resour. Res., Vol. 30, No. 9, pp. 2533-2546, 1994.

Nolte, D. D., L.J. Pyrak-Nolte and N.G.W. Cook. The Fractal Geometry of the Flow Paths in Natural Fractures in Rock and the Approach to Percolation, Pure and Applied Geophysics, Vol. 131, Nos. 1/2, pp. 111-138, 1989.

Palumbo, A. V., J. F. McCarthy, A. Parker, S. Pfiffner, F. S. Colwell and T. J. Phelps, Potential for microbial growth in arid subsurface sediments, Applied Biochemistry and Biotechnology, vol. 45/46, 823-834, 1994.

Parker, B. L., R. W. Gillham and J. A. Cherry, Diffusive disappearance of immisciblephase organic liquids in fractured geologic media, Ground Water, vol. 32, no. 5 805-820, 1994.

Parker, B. L., J. A. Cherry and R. W. Gillham, The effects of molecular diffusion on DNAPL behavior in fractured porous media, in Dense Chlorinated Solvents and other DNAPLs in Groundwater: History, Behavior and Remediation, J. F. Pankow and J. A. Cherry, eds., Waterloo Press, 355-393, 1996.

Persoff, P. and Pruess, K., Flow visualization and relative permeability measurements in rough-walled fractures, in Proceedings of the Fourth International High-Level Radioactive Waste Management Conference, Las Vegas, Nevada, April 26-30, 1993, vol. 2, pp. 2007-2019, American Sociéty of Civil Engineers, New York, 1993.

Persoff, P. and K. Pruess, Two-phase flow visualization and relative permeability measurement in natural rough-walled rock fractures, Water Resour. Res., Vol. 31, No. 5, pp. 1173-1186, 1995.

Powers, S. E., W. H. Anckner and T. F. Seacord, The wettability of NAPL-contaminated sands, ASCE Journal of Environmental Engineering, vol. 122, no. 10, 889-896, 1996.

Pruess, K. TOUGH2 - A General Purpose Numerical Simulator for Multiphase Fluid and Heat Flow, Lawrence Berkeley Laboratory Report LBL-29400, Lawrence Berkeley Laboratory, Berkeley, CA, May 1991.

Pruess, K. On Water Seepage and Fast Preferential Flow in Heterogeneous, Unsaturated Rock Fractures. J. Contam. Hydr.. Vol. 30, No. 3-4, pp. 333 - 362, 1998a.

Pruess, K. A Mechanistic Model for Water Seepage through Thick Unsaturated Zones in Fractured Rocks of Low Matrix Permeability, submitted to Water Resour. Res., 1998b. 
Pruess, K., and Y. W. Tsang. On Two-Phase Relative Permeability and Capillary Pressure of Rough-Walled Rock Fractures, Water Resour. Res.. Vol. 26, No. 9, pp. 19151926, September 1990.

Pruess, K. and E. Antunez. Applications of TOUGH2 to Infiltration of Liquids in Media with Strong Heterogeneity, Proceedings of the TOUGH Workshop '95, Lawrence Berkeley Laboratory Report LBL-37200, pp. 69-76, Berkeley, CA, March 1995 (also: Lawrence Berkeley Laboratory Report LBL-36872).

Richards, L. A. Capillary Conduction of Liquids Through Porous Mediums, Physics, 1, 318-333, 1931.

Riddick, J. A., and W. B. Bunger, Organic Solvents - Physical Properties and Methods of Purification, Wiley-Interscience, New York, NY, $3^{\text {rd }}$ ed., 1970.

Roberts, J. R., J. A. Cherry and F. W. Schwartz, A case study of a chemical spill: Polychlorinated Biphenyls (PCBs) 1. History, Distribution and Surface Translocation, Water Resources Research, vol. 18, no. 3, 525-534, 1982.

Rousseau, J.P., E.M. Kwicklis and D.C. Gillies (eds.), Hydrogeology of the Unsaturated Zone, North Ramp Area of the Exploratory Studies Facility, Yucca Mountain, Nevada, U.S. Geological Survey Water Resources Investigations Report, Denver, CO, 1997.

Seely, G. E., R. W. Falta and J. R. Hunt, Buoyant advection of gases in unsaturated soil, Journal of Environmental Engineering, vol. 120, no. 5, 1230-1247, 1994.

Sorenson, Jr., K. S., A. H. Wylie and T. R. Wood, Test Area North Hydrogeologic Studies Test Plan Operable Unit 1-07B, Idaho' National Engineering Laboratory, Report No. INEL-96/0105, March, 1996.

Su, G., J. T. Geller, K. Pruess and F. Wen, Experimental studies of water seepage and intermittent flow in unsaturated, rough-walled fractures, submitted to Water Resources Research, in press, 1999.

Tchobanoglous, G. and E. D. Schroeder, Water Quality, Addison-Wesley Publishing Company, Reading, MA, 768 p., 1987.

Tompson, A.F.B. Implementation of the Three-Dimensional Turning Bands Random Field Generator, Water Resour. Res., Vol. 25, No. 10, pp. 2227 - 2243, 1989.

Wang, J.S.Y. and T.N. Narasimhan. Hydrologic Mechanisms Governing Fluid Flow in a Partially Saturated, Fractured, Porous Medium, Water Resour. Res., 21 (12), 1861 1874, December 1985.

Wang, J.S.Y., T.N. Narasimhan, and C.H. Scholz. Aperture Correlation of a Fractal Fracture, Journal of Geophysical Res.. 93 (B3), 2216-2224, 1988.

Whitehead, R. L., Geohydrologic Framework of the Snake River Plain Regional Aquifer System, Idaho and Eastern Oregon, U.S. Geological Survey professional paper 
1408-B, U.S. Department of the Interior, U.S. Geological Survey, Denver, CO, 1992.

Zheng, M., and S. T. Kellogg, Analysis of bacterial populations in a basalt aquifer, Can. Jo. of Microbiol., vol. 40, no. 11, 944-954, 1994. 
Table 1: Properties of liquids used in the seepage experiments

(at $25^{\circ} \mathrm{C}$ and atmospheric pressure unless otherwise noted)

\begin{tabular}{|c|c|c|c|c|c|}
\hline Liquid & $\begin{array}{c}\text { Density }^{2} \\
\left(\mathrm{~kg} / \mathrm{m}^{3}\right) \\
\text { (pure liquids) }\end{array}$ & $\begin{array}{c}\text { Viscosity }^{\mathrm{a}} \\
\left(10^{-3} \mathrm{~Pa}-\mathrm{s}\right) \\
\text { (pure liquids) }\end{array}$ & $\begin{array}{c}\text { Air/liquid } \\
\text { surface tension } \\
(\mathrm{mN} / \mathrm{m}) \\
\text { (dyed liquids) }^{\mathrm{b}}\end{array}$ & $\begin{array}{c}\text { Contact angle on } \\
\text { epoxy (degrees) } \\
\text { (dyed liquids) }^{\mathrm{b}}\end{array}$ & $\begin{array}{l}\text { Vapor pressure } \\
\text { (mm Hg) } \\
\text { (pure liquids) }\end{array}$ \\
\hline Water & $997^{8}$ & $1.103^{\mathrm{g}}$ & $64.4^{\mathrm{c}}$ & $62^{\mathrm{c}}$ & $23.8^{\mathrm{g}}$ \\
\hline n-dodecane & 745 & 1.378 & $25.2^{\mathrm{d}}$ & $0^{\mathrm{f}}$ & $0.12^{\mathrm{h}}$ \\
\hline PCE & 1630 & 0.89 & $31.2^{\mathrm{d}}$ & $0^{\mathrm{f}}$ & $17.8^{\mathrm{i}}$ \\
\hline \multicolumn{6}{|c|}{ a. Riddick and Bunger (1970) } \\
\hline \multicolumn{6}{|c|}{ Water dyed with $0.4 \%$ Liquitint; NAPLs dyed with $1 \mathrm{mg} / \mathrm{L}$ Spectra Oil Red } \\
\hline \multicolumn{6}{|c|}{ c. Geller et al. (1996), $21^{\circ} \mathrm{C}$} \\
\hline \multicolumn{6}{|c|}{ Measured with surface tensiometer (model 21 , Fischer Scientific), $21^{\circ} \mathrm{C}$} \\
\hline \multicolumn{6}{|c|}{ Measured with goniometer (Ramé-Hart, Inc., Mountain Lakes, N. J.), $21^{\circ} \mathrm{C}$} \\
\hline \multicolumn{6}{|c|}{ Direct observation } \\
\hline \multicolumn{6}{|c|}{ Tchobanoglous and Schroeder (1987) } \\
\hline \multicolumn{6}{|c|}{ 1. Mackay and Shin (1974) } \\
\hline \multicolumn{6}{|c|}{ i. Mercer and Cohen (1990) } \\
\hline
\end{tabular}




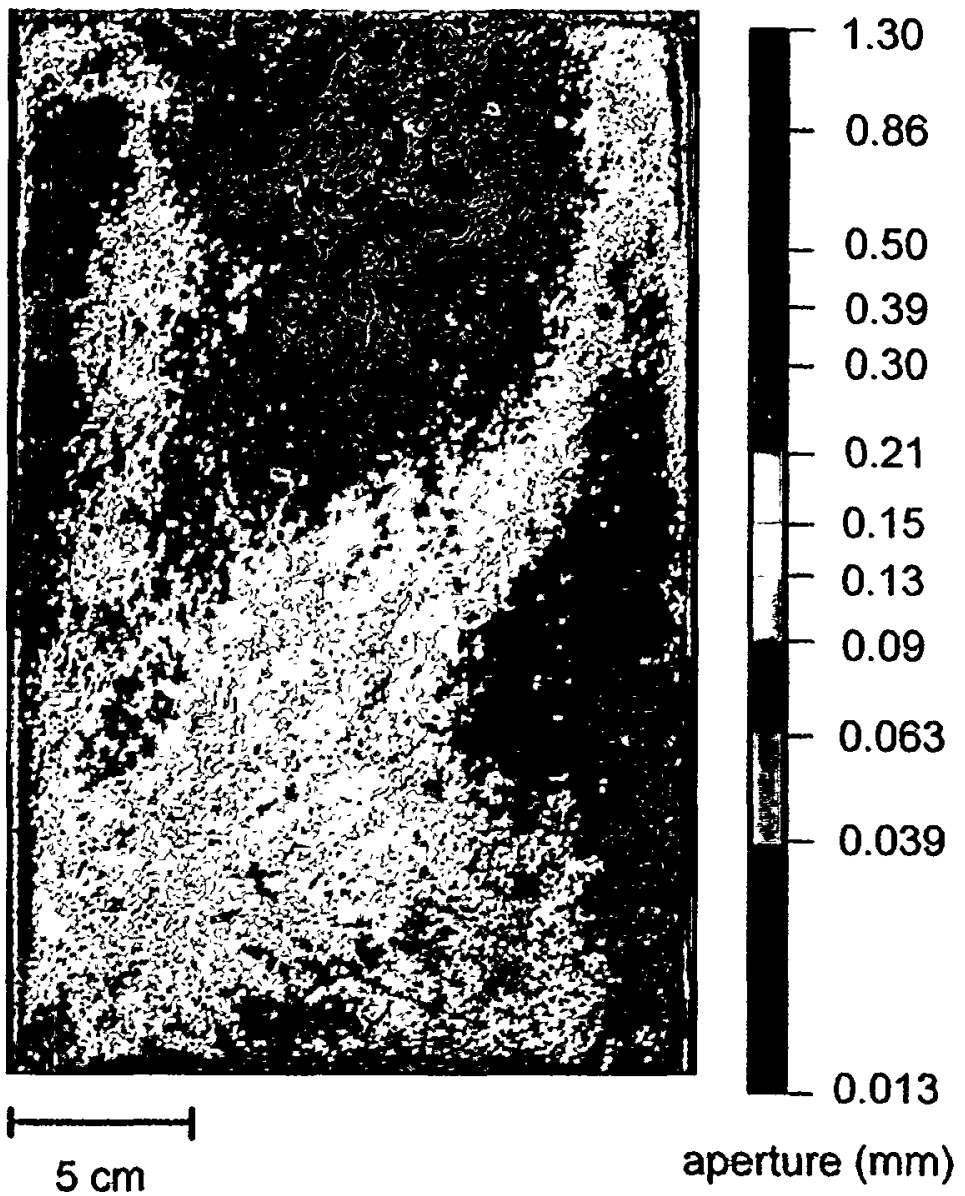

Figure 1. Aperture map of epoxy replica of natural granite fracture measured from light attenuation (from Su et al., 1999). 


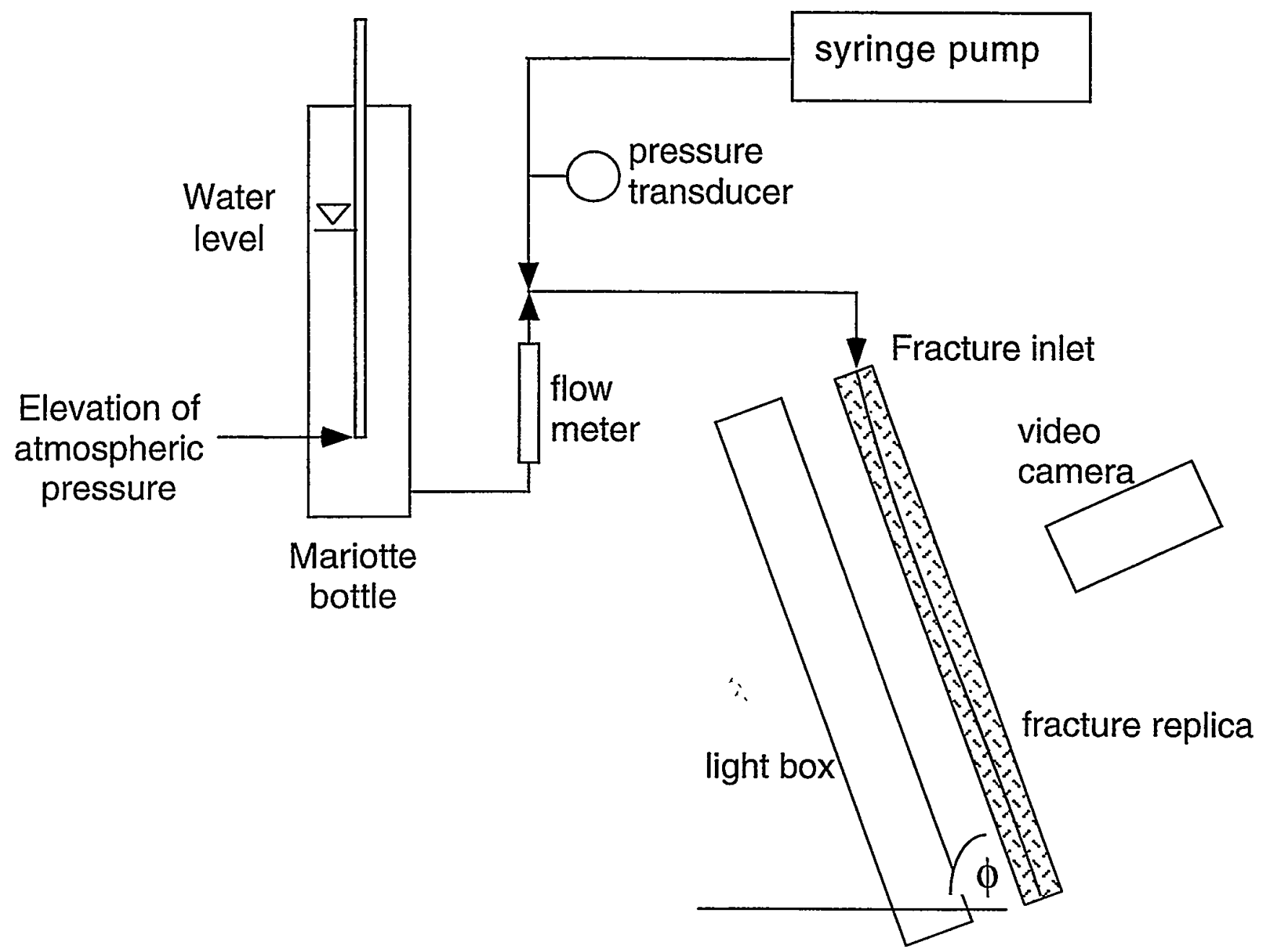

Figure 2. Water delivery to fracture replica, either by syringe pump for constant flow, or by Mariotte bottle for constant pressure 


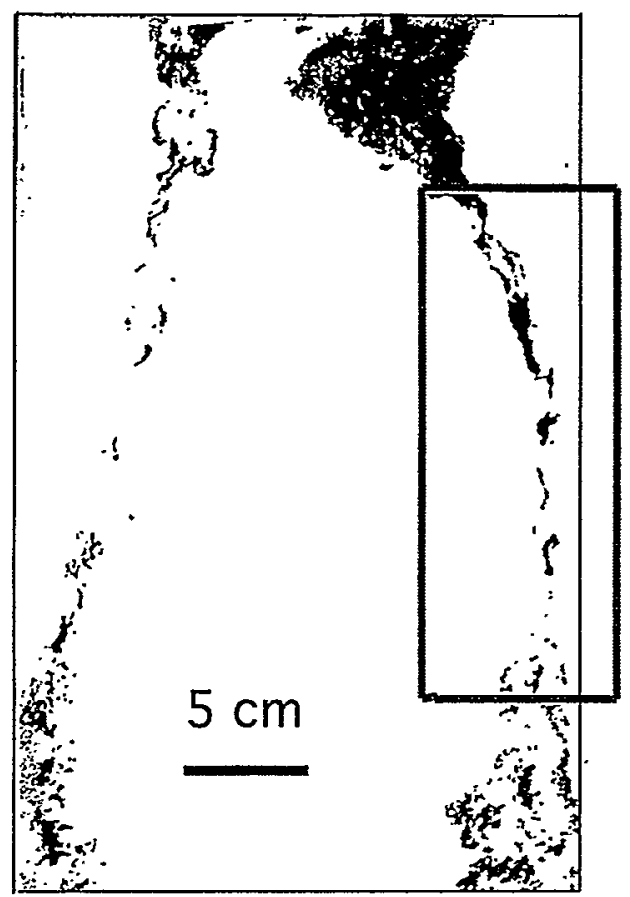

(a) $t=12: 39-1$

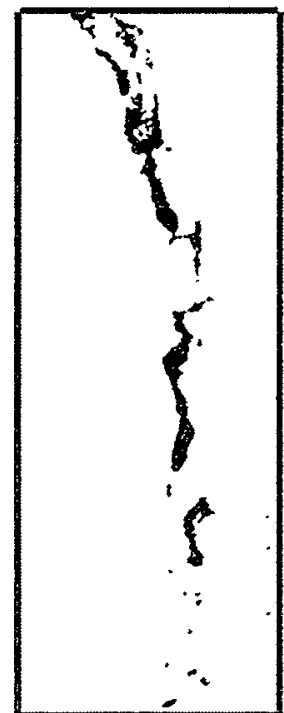

(b) $t=12: 39-2$

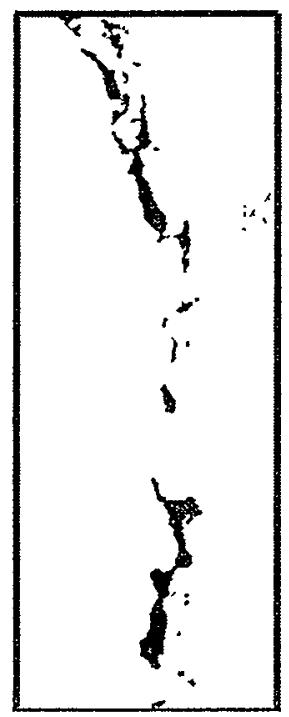

(c) $t=12: 39-3$

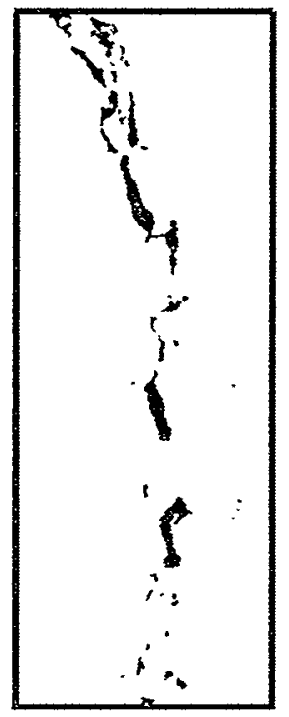

(d) $t=12: 39-4$

Figure 3. Water distribution during percolation, fracture inclined $70^{\circ}$ from the horizontal, inlet water tension $=-3.5 \mathrm{~cm} \mathrm{H}_{2} \mathrm{O}$. Flow channels appear disconnected, but water is flowing through the right channel along narrow rivulets that connect larger liquid-filled regions, as indicated by the change in distribution with time. Images are within seconds of one another. (b)-(d) are enlargements of boxed area in (a). 

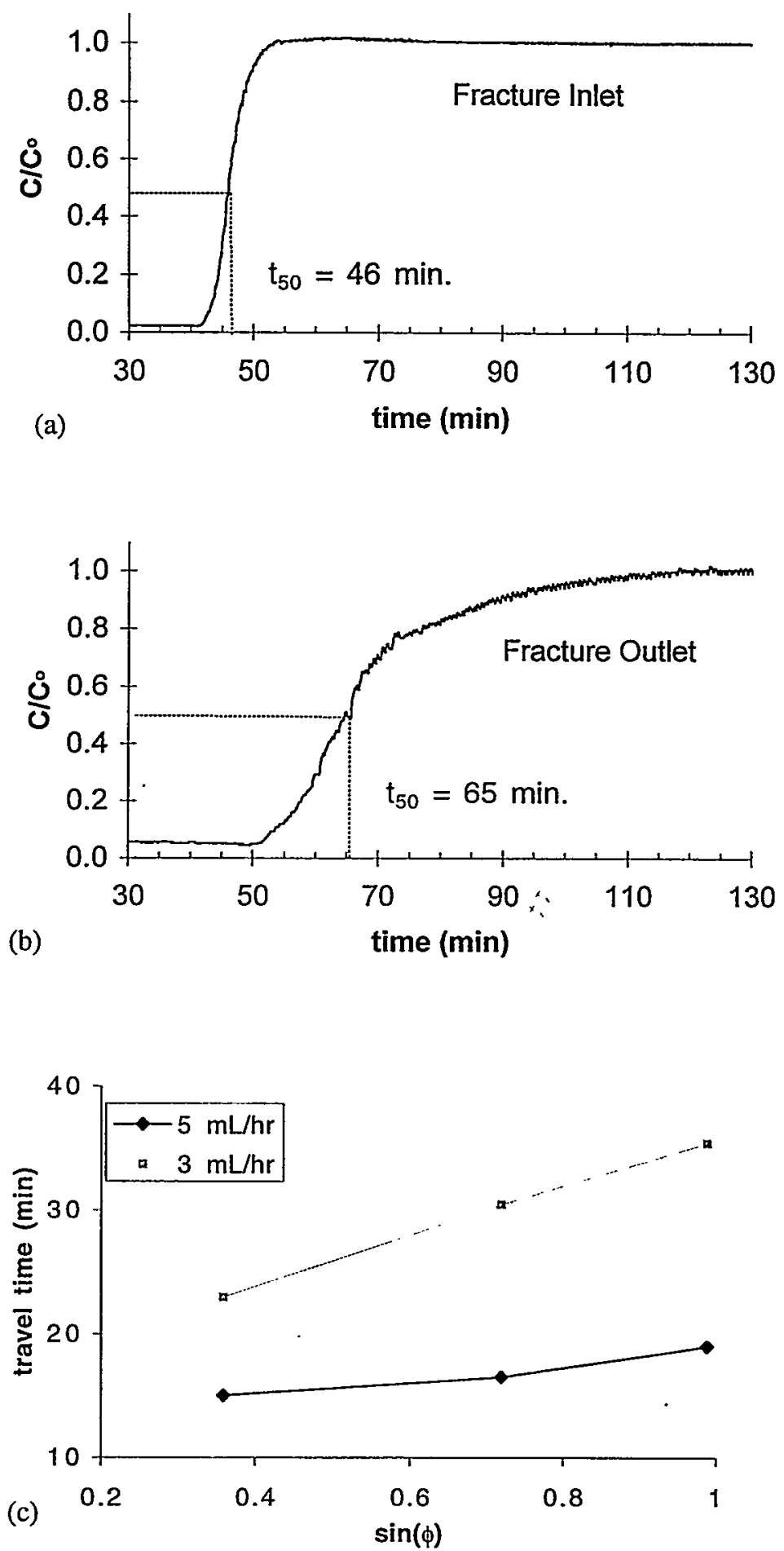

Figure 4. (a) and (b) Breakthrough curves from tracer test in fracture replica for $5 \mathrm{~mL} / \mathrm{hr}, 81^{\circ}$ inclination from the horizontal. (a) Fracture inlet. (b) Fracture outlet. (c) Travel time is measured from the difference of the times at $C / C_{0}=0.5$ 


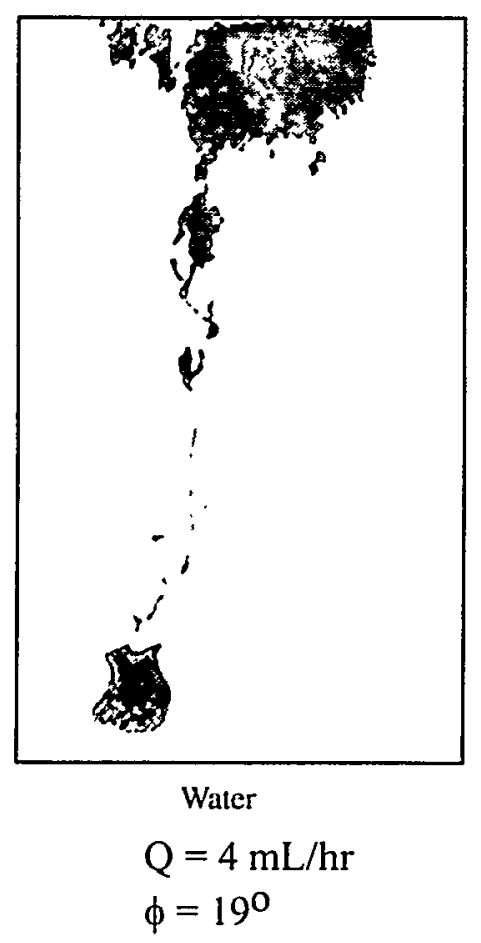

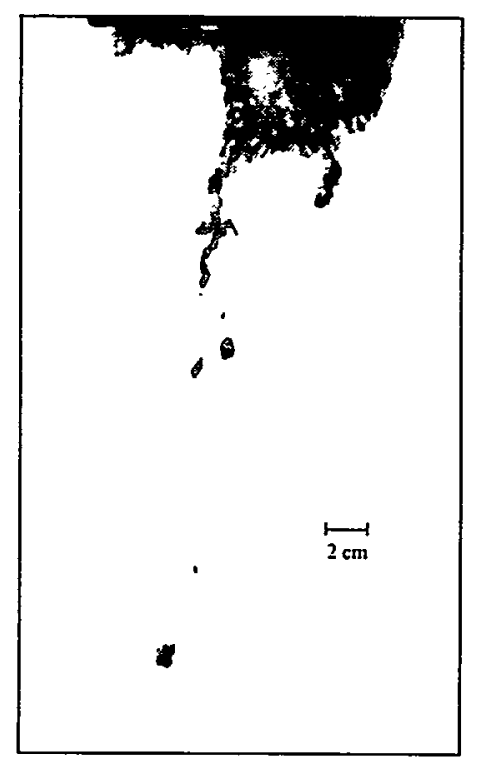

n-Dodecane

$\mathrm{Q}=4 \mathrm{~mL} / \mathrm{hr}$

$\phi=23^{\circ}$

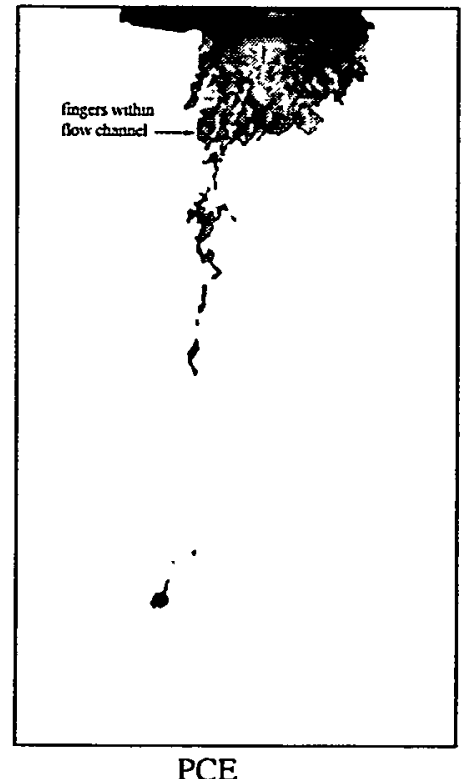

$\mathrm{Q}=6 \mathrm{~mL} / \mathrm{hr}$

$\phi=19^{\circ}$

Figure 5. Liquid distribution during three seepage experiments for water, $n$-dodecane and PCE into the initially dry fracture replica. Grey indicates liquid-occupied regions, white regions are dry. Images were taken immediately before the initial invading finger broke through the fracture outlet. 


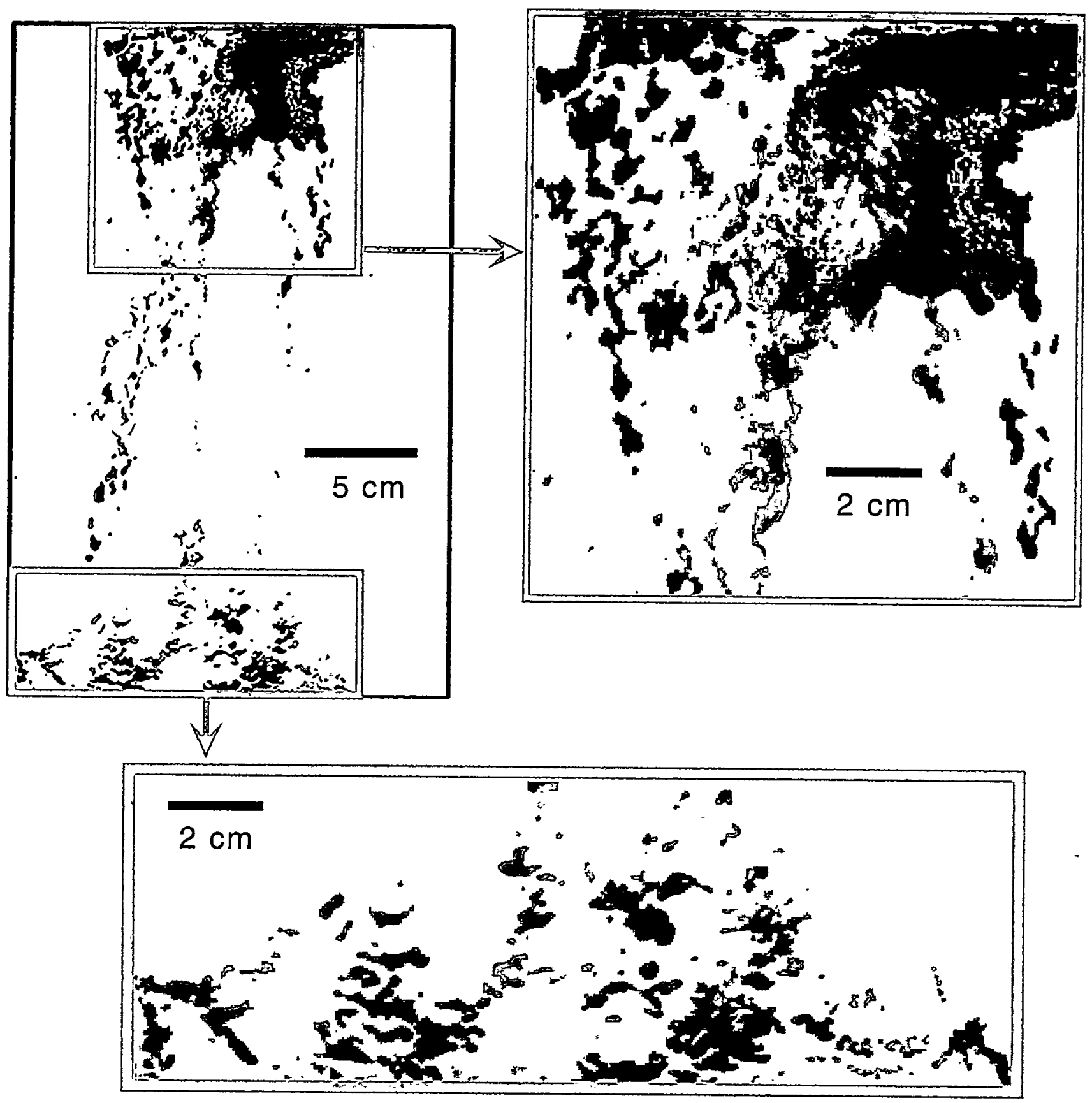

Figure 6. Distribution of NAPL (dodecane, dyed red) introduced into fracture replica containing residual water (dyed blue). Enlarged sections show NAPL trapping along air/water/solid contacts. 


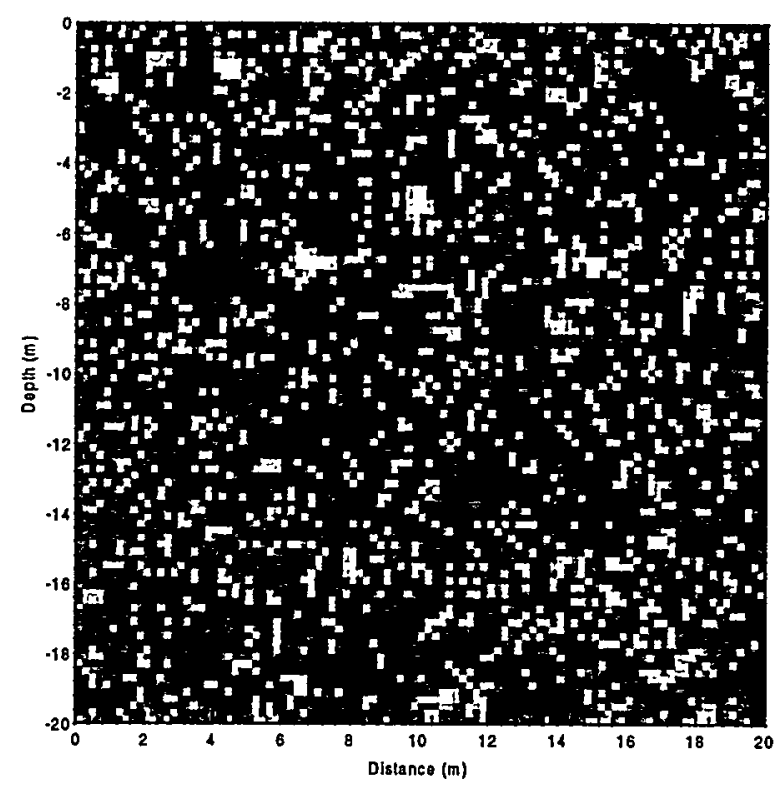

$$
\begin{aligned}
& \text { Permeability } \\
& \text { modifier, } \zeta
\end{aligned}
$$

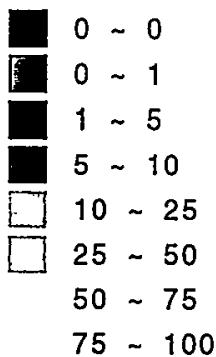

(a) shifted log-normal, standard Metropolls

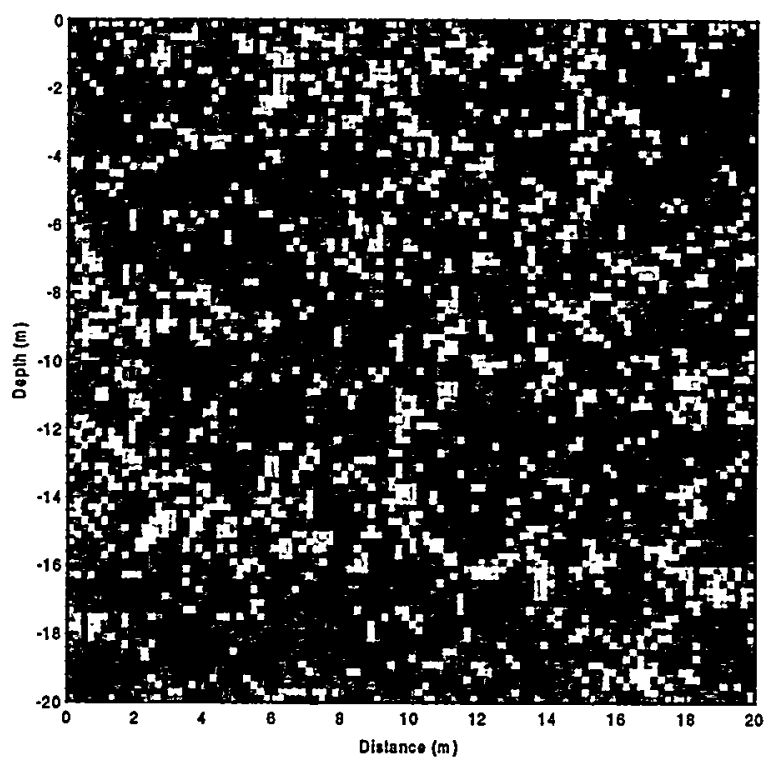

(b) shifted log-normal, modified Metropolis, first neighborhood

Figure 7. Synthetic spatially-correlated permeability fields representating heterogeneous fractures. (a) The standard Metropolis algorithm generates spatially scattered asperity contacts, (b) our modified approach improves clustering into simply-connected regions. 


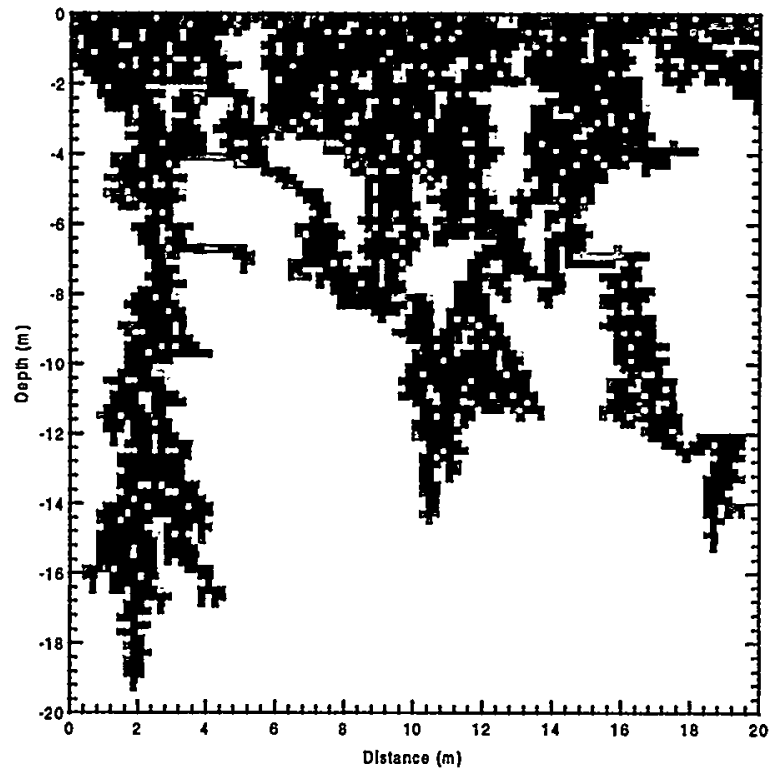

(a) standard Metropolis, $T=39.27$ hrs

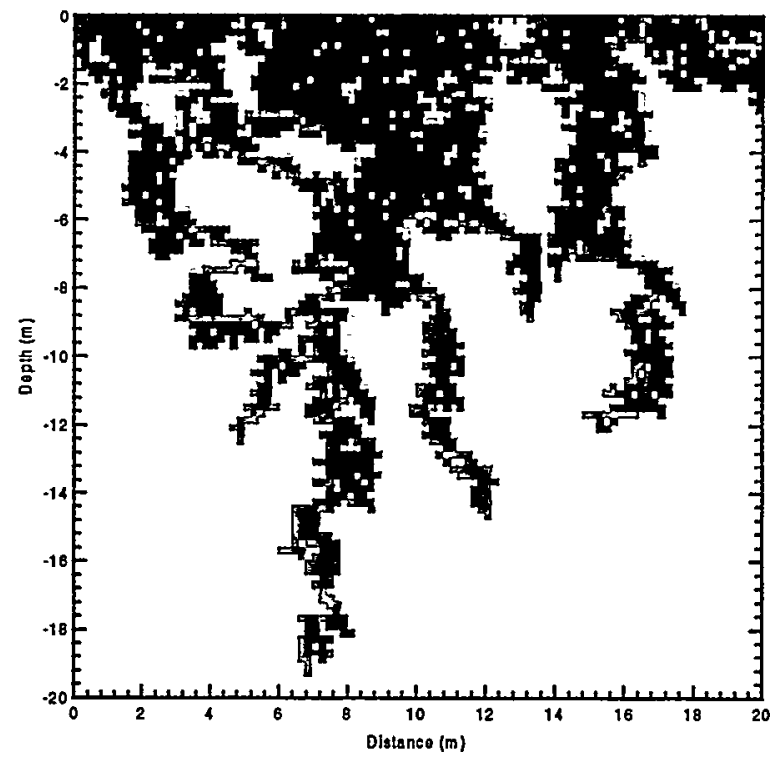

(b) modified Metropolis, first nelghborhood, $T=38.57$ hrs
Liquid

Saturation

$0.99 \sim 1.00$
$0.80 \sim 0.99$
$0.60 \sim 0.80$
$0.40 \sim 0.60$
$0.20 \sim 0.40$
$0.15 \sim 0.20$

Figure 8. Simulated liquid seeps shown at the time of breakthrough at the bottom boundary for the fractures shown in Fig. 7 . W ater was injected at a constant rate of $10^{-3} \mathrm{~kg} / \mathrm{s}$ uniformly over the entire top boundary of the fracture. 


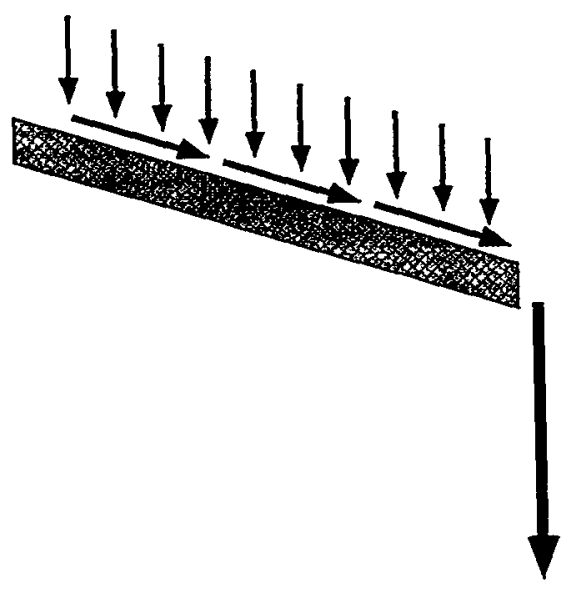

(a) one-sided funnel

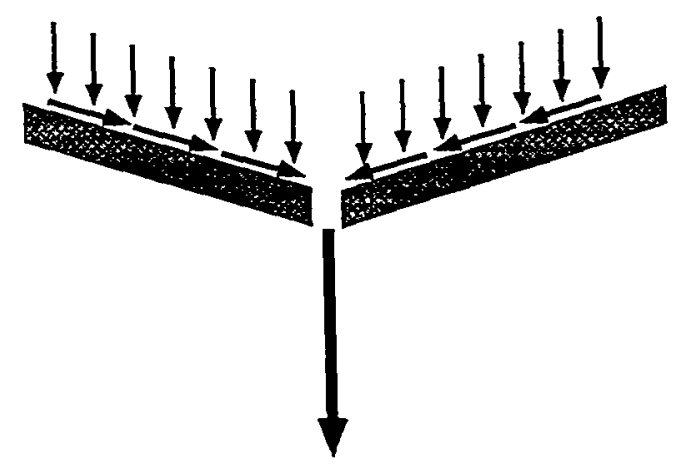

(b) two-sided funnel

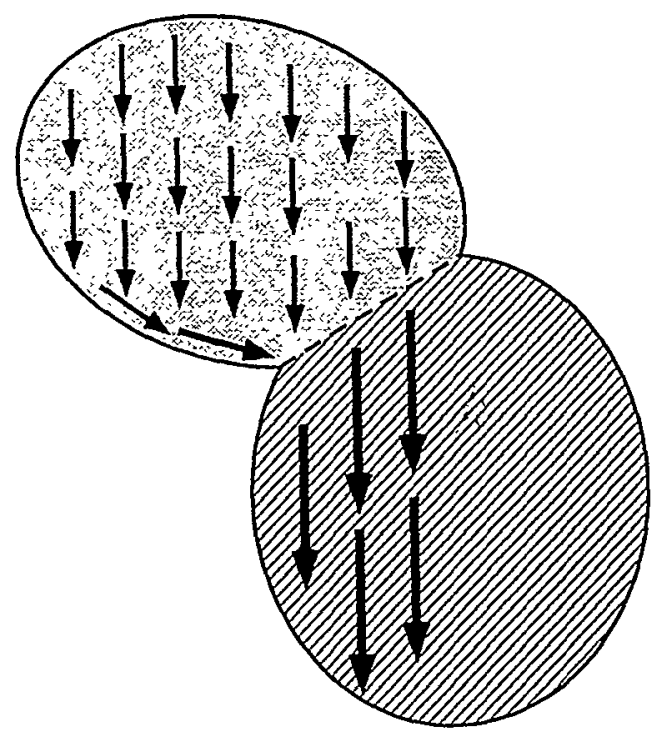

(c) fracture intersection/termination

Figure 9. Schematic of heterogeneity structures that can give rise to focusing of spatially distributed flows into localized pathways, from Pruess (1998b). 


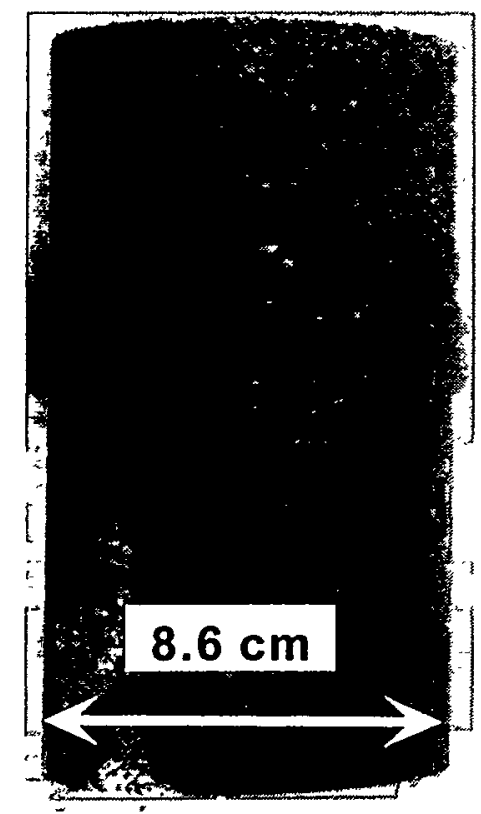

(a)

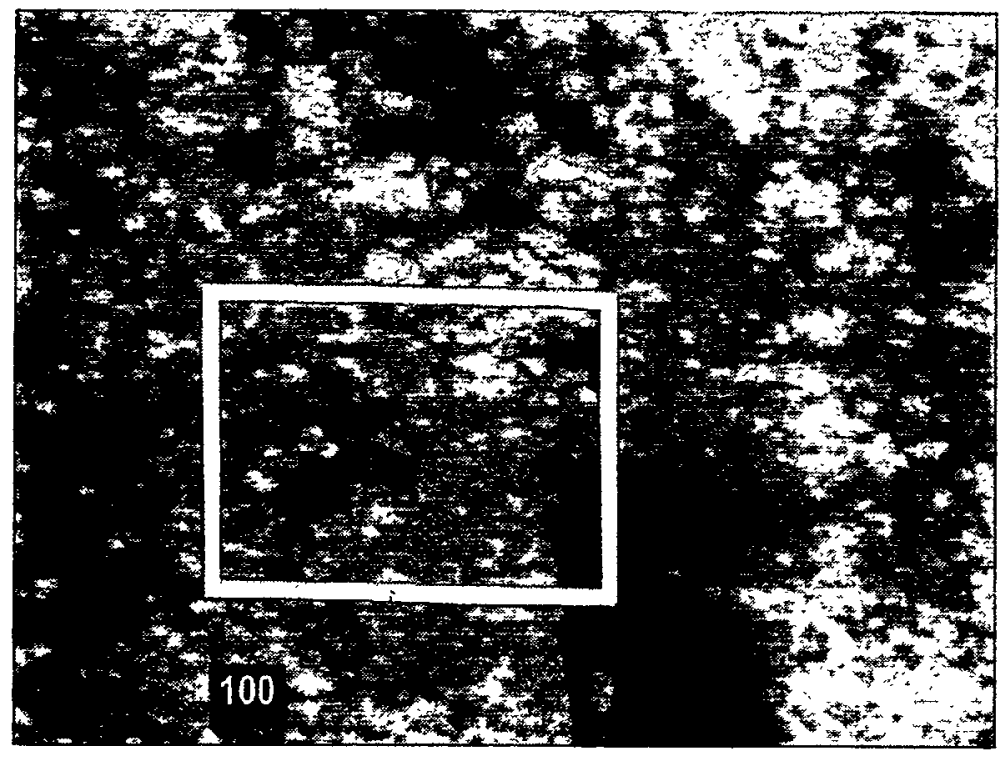

(b)

Figure 10. (a) The 8.6-cm diameter core sample from INEEL; (b) Microphotography of the $400 \mu \mathrm{m} \times 500 \mu \mathrm{m}$ study area. Axis BB' is the sampling path for Figure 13. The two prominent dark areas are two vesicles in the basalt specimen. 


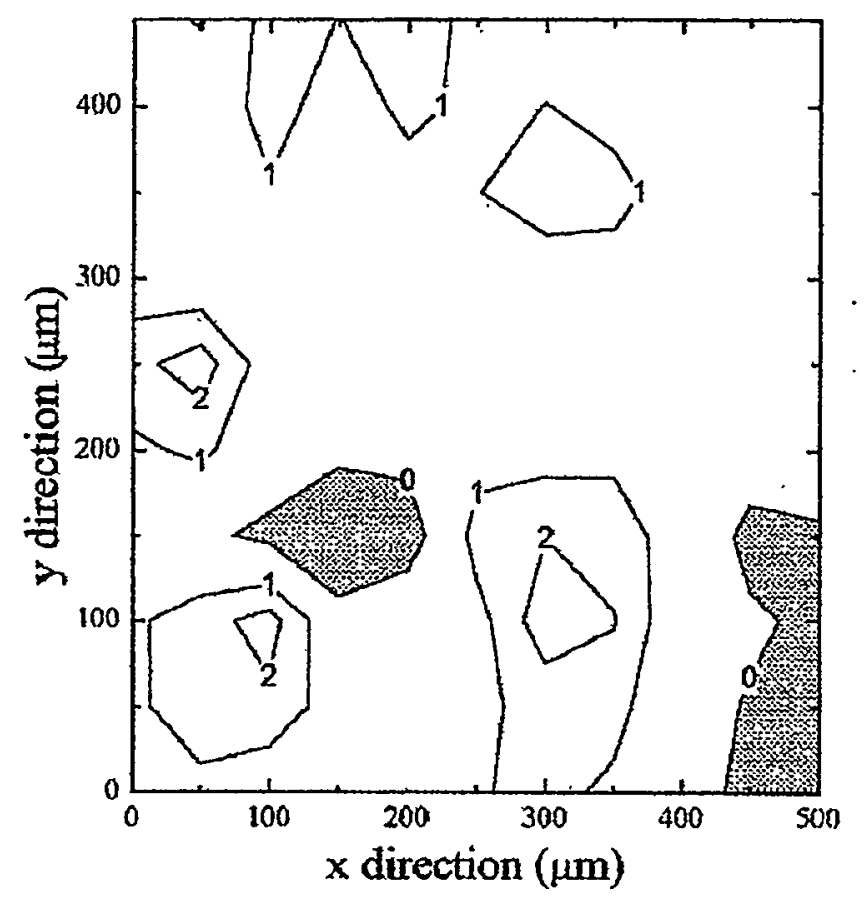

(a)

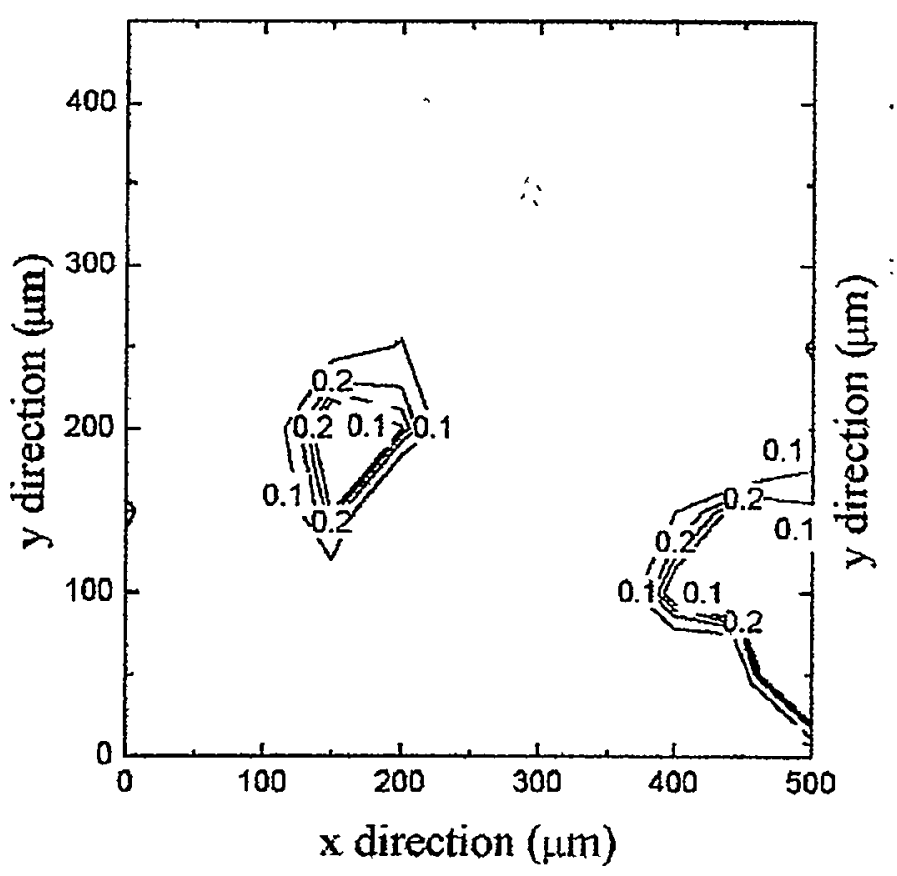

(b)

Fig. 11. Contour plots of the study area in Fig. 10 (b) based on absorption intensity of (a) silicate-containing minerals in basalt in the $1300-800 \mathrm{~cm}^{-1}$ region. (b) microbial protein Amide I at $1650 \mathrm{~cm}^{-1}$ 

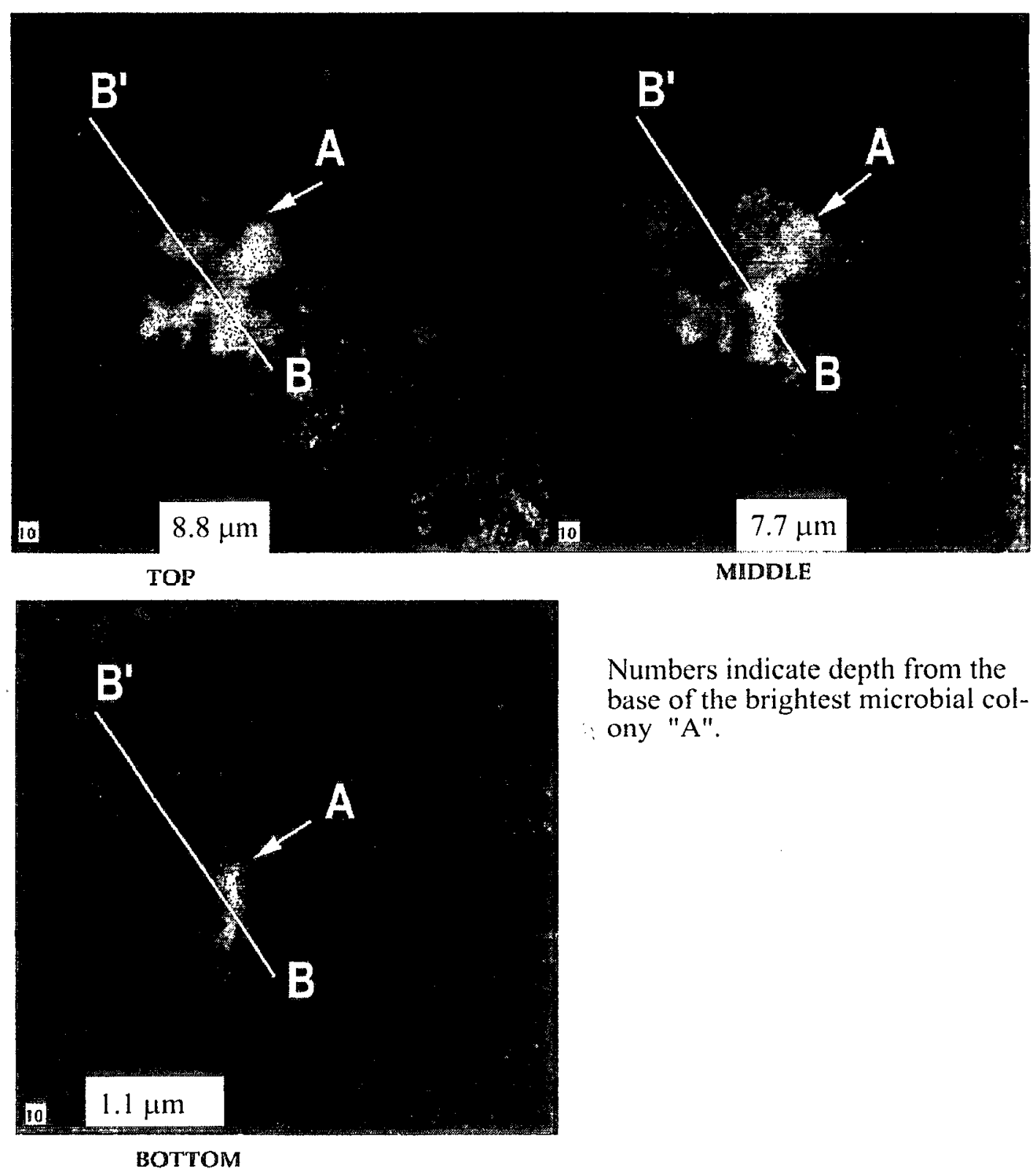

Numbers indicate depth from the base of the brightest microbial colony "A".

Fig 12. Confocal fluorescence micrograph of $x-y$ sections showing images of microbial clusters at three different optical depths on the vesicular basalt sample. The microbes were observed with simultaneous excitation at 488 and $514 \mathrm{~nm}$. Axis BB' is the same sampling path shown in the microphotograph in Figure 10 (b). 

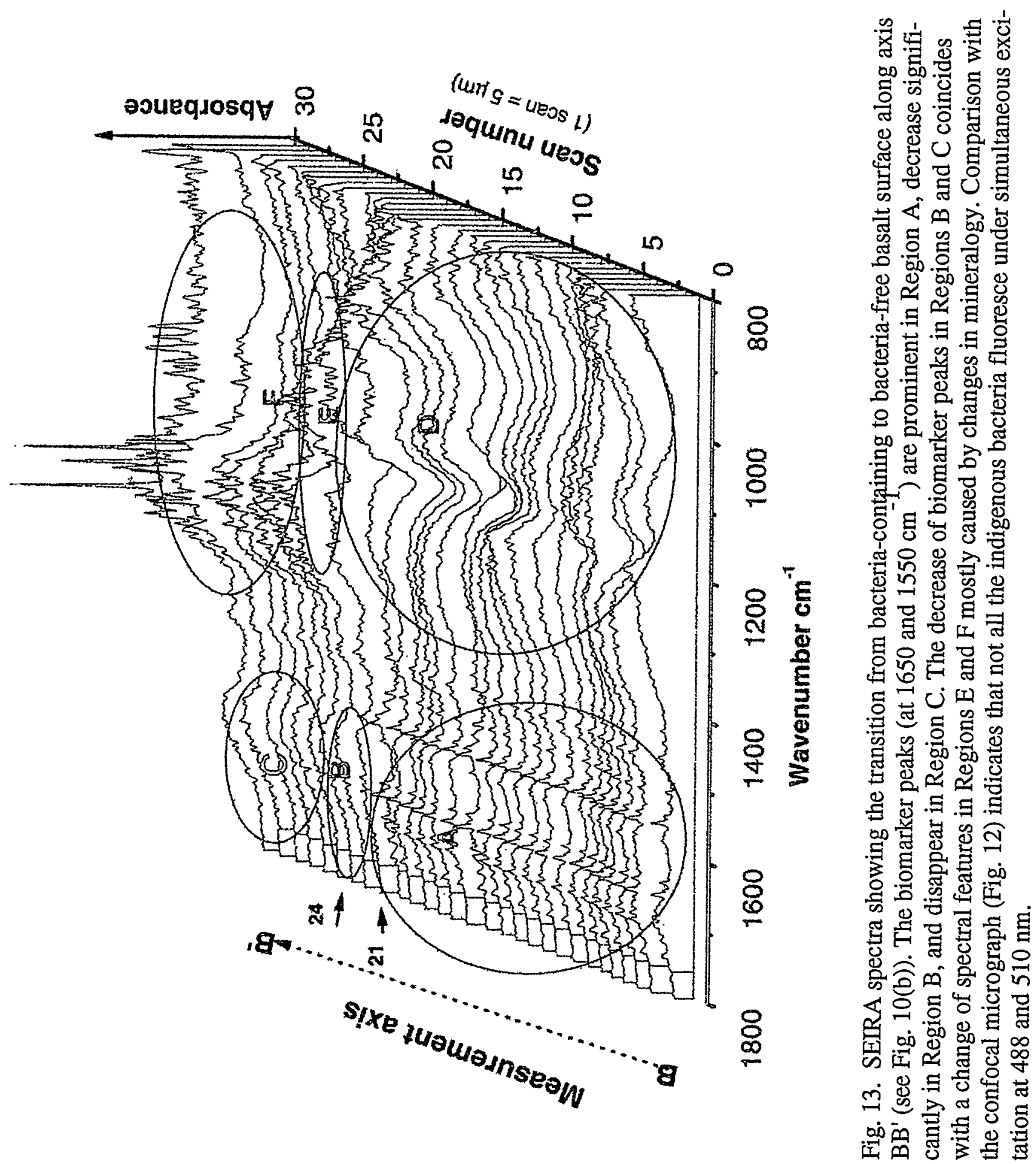


\section{$100 \%$ RH}

\section{$\mathrm{t}=\mathbf{5}$ days}
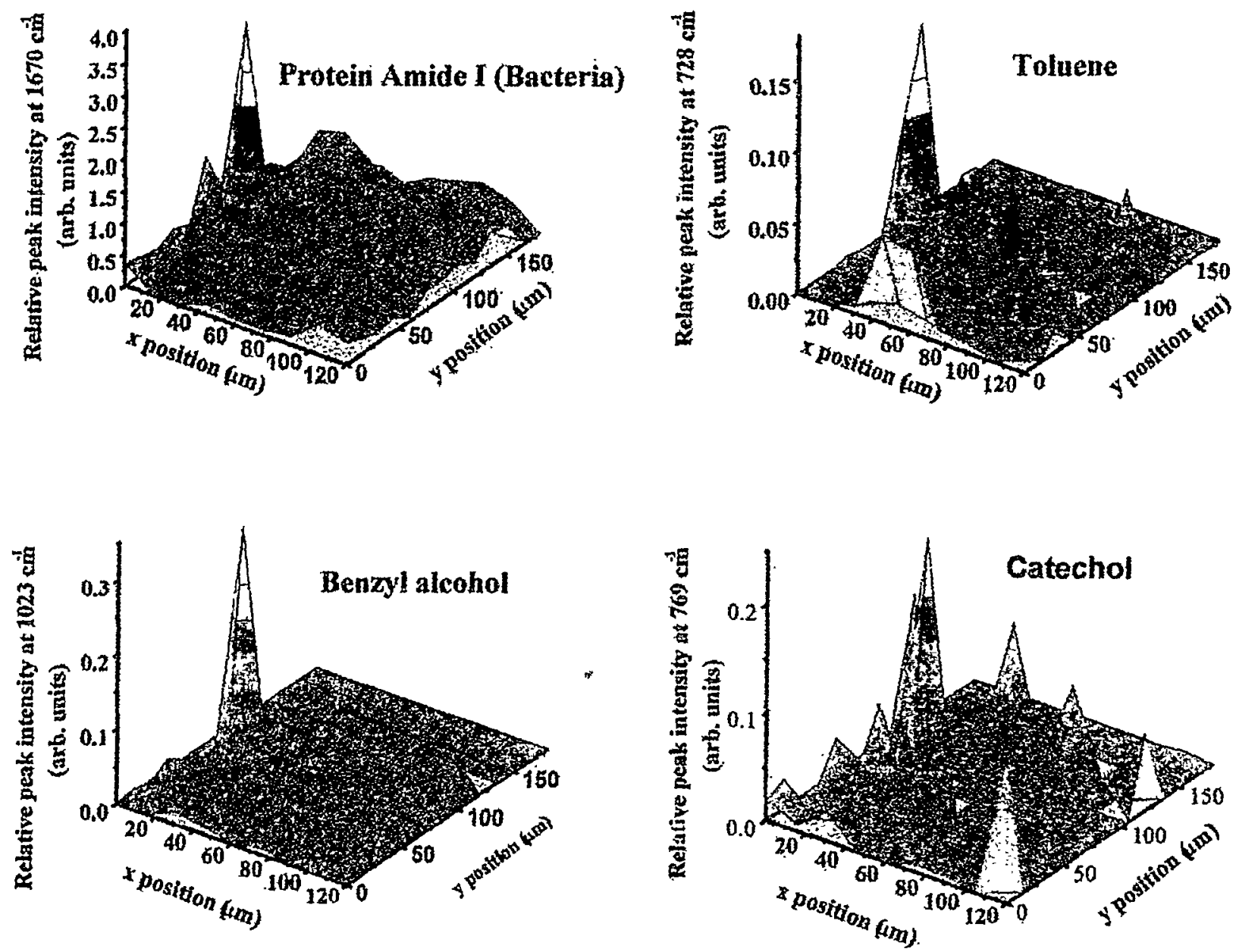

Figure 14. Arthrobacter oxydans bacteria, isolated from our rock sample, re-attached themselves to the rock surfaces. The specimen was exposed to toluene vapor with near-100\% RH for 5 days. We locate the bacteria, toluene, and the toluene early metabolites on the rock surfaces via their spectral signature. We observed peak toluene and its early metabolites near the peak locations of $A$. oxydans, implying that the toluene was sorbed to the bacterial cells. 


\section{$25 \%$ RH \\ $\mathbf{t}=\mathbf{5}$ days}
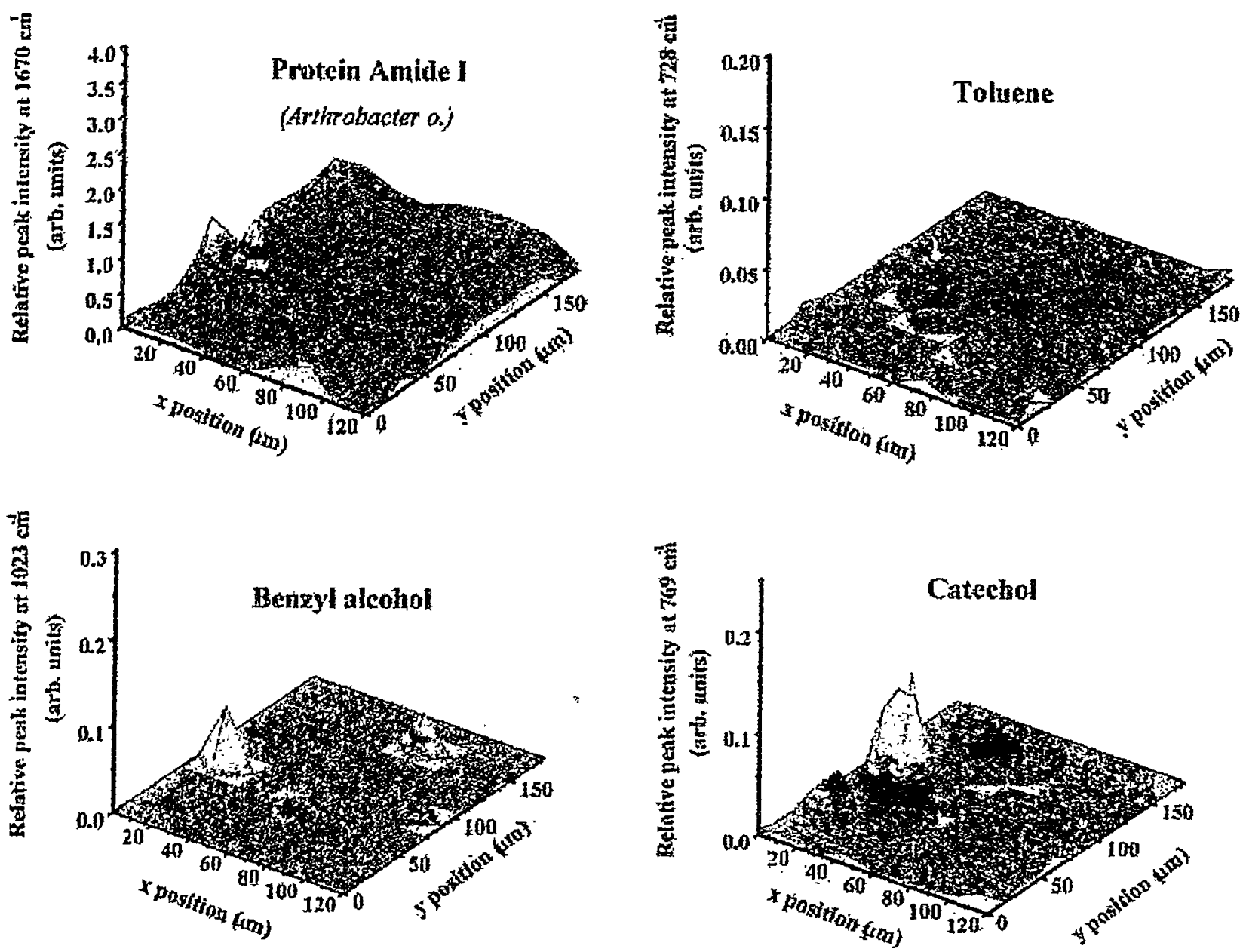

Figure 15. The same specimen in Fig. 14 was returned to toluene vapor with $25 \%$ RH for 5 days. Biomass, sorbed toluene and the toluene early metabolites on the rock surface decreased significantly relative to the more moist conditions. 

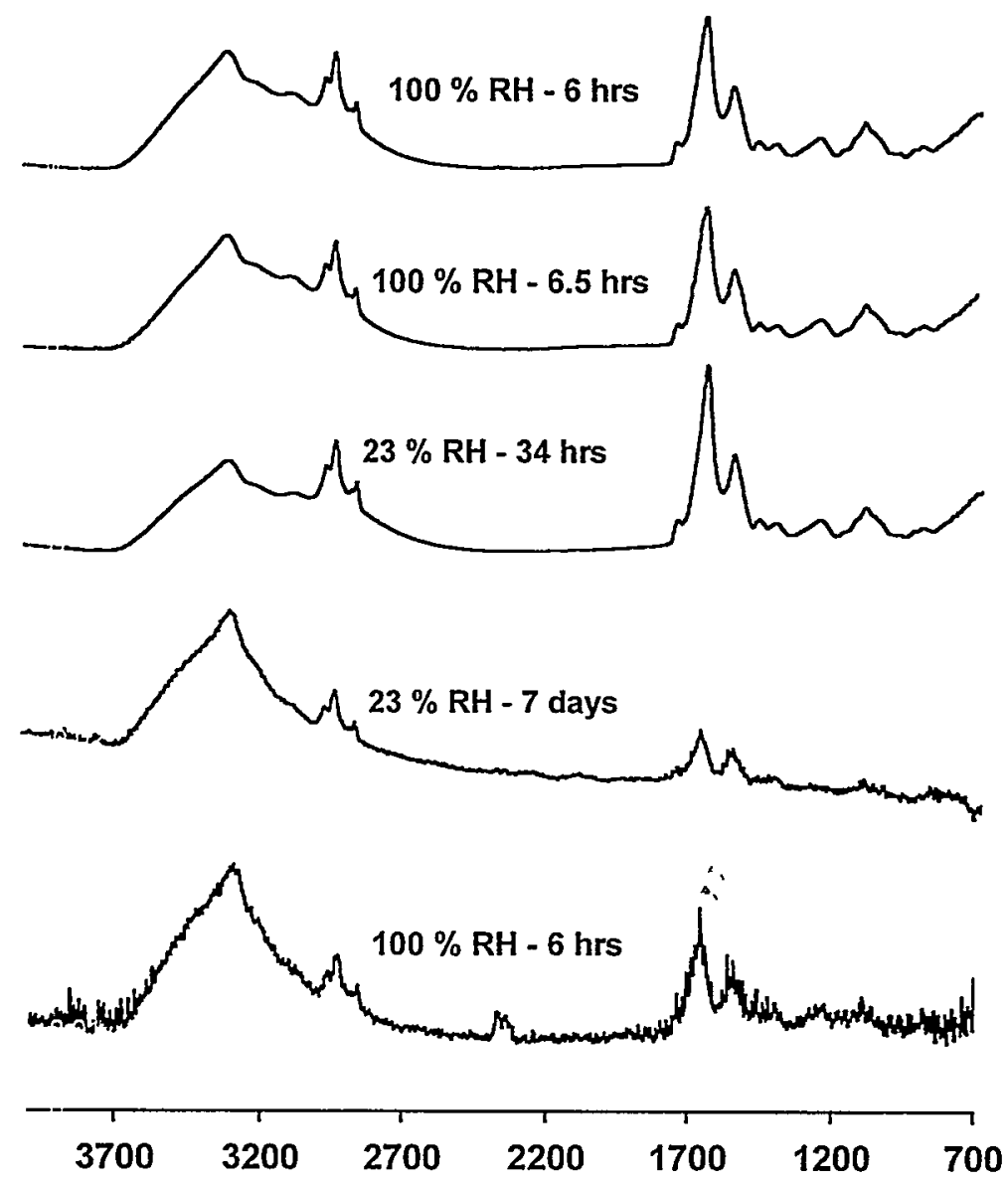

Wave Number $\left(\mathrm{cm}^{-1}\right)$

Figure 16 FTIR spectra recorded from the Gram-negative bsalt inhabiting bacteria on an aluminized microscope slide coated with a thin film of basalt extract. The decline and subsequent increase in the biomarker peaks shows that bacteria that have been exposed to dry air can be revived with exposure to $100 \% \mathrm{RH}$. 


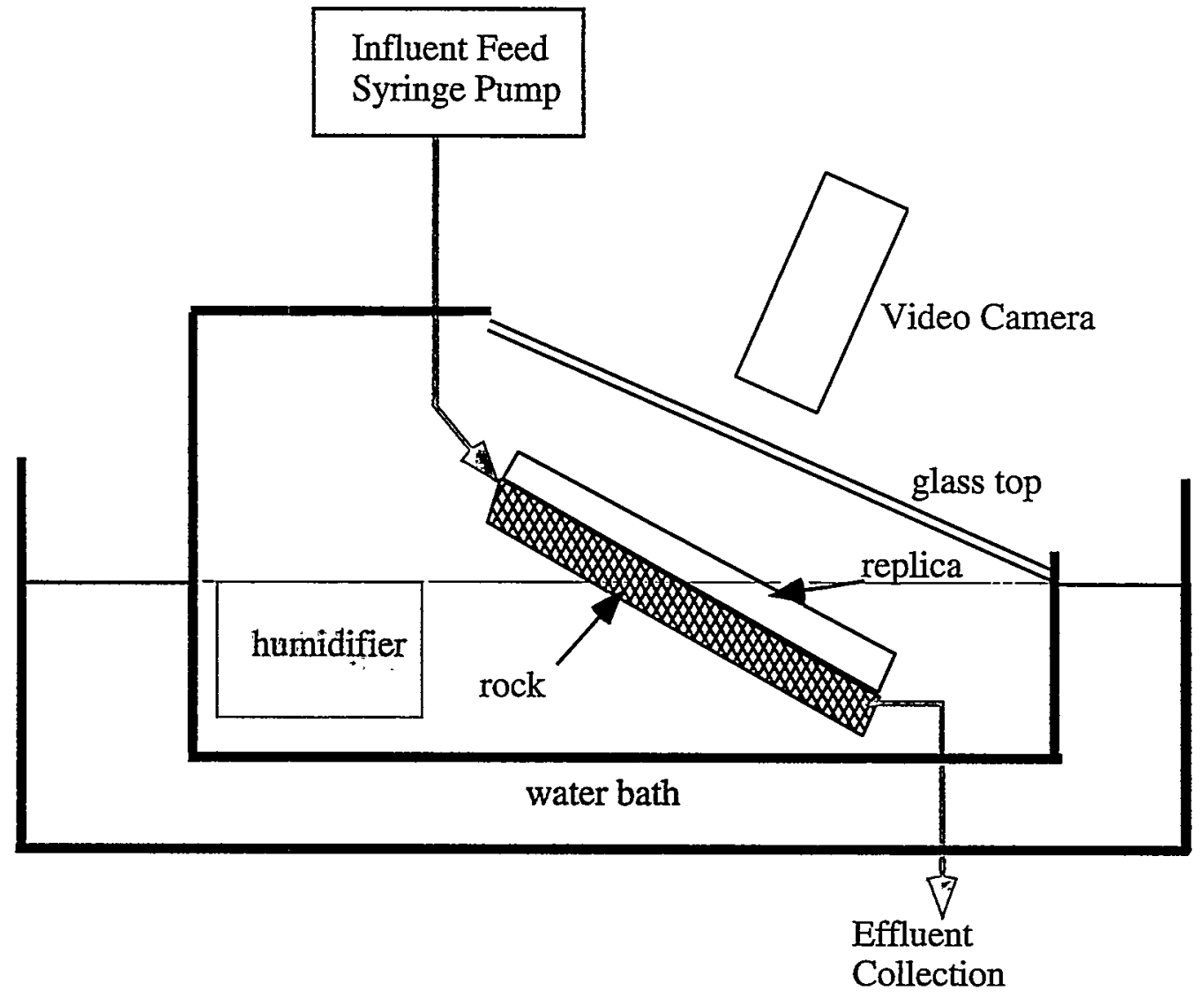

Figure 17. Open geocosm experimental apparatus 


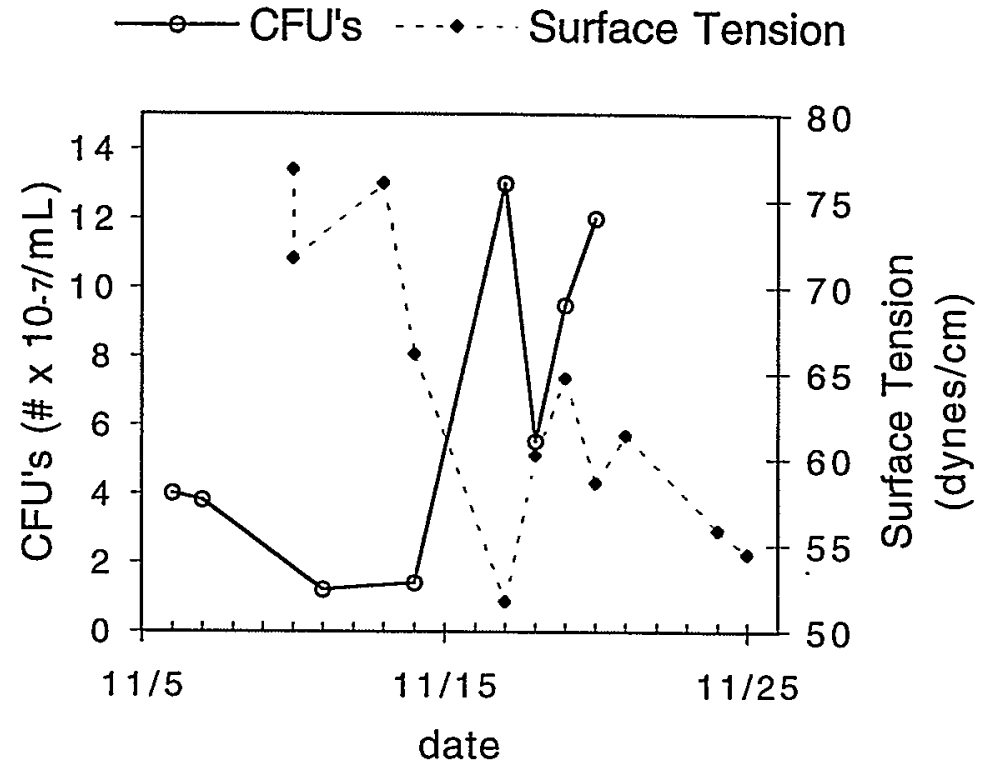

Figure 18. Colony forming units and surface tension changes in rock-replica geocosm effluent 

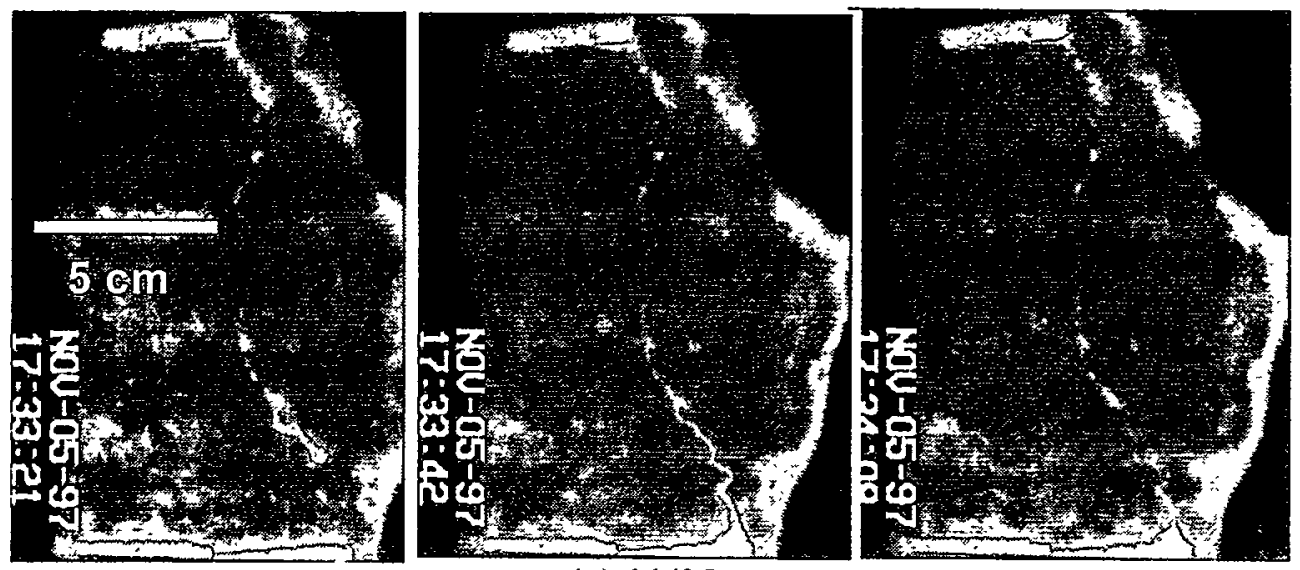

(a) $11 / 05$
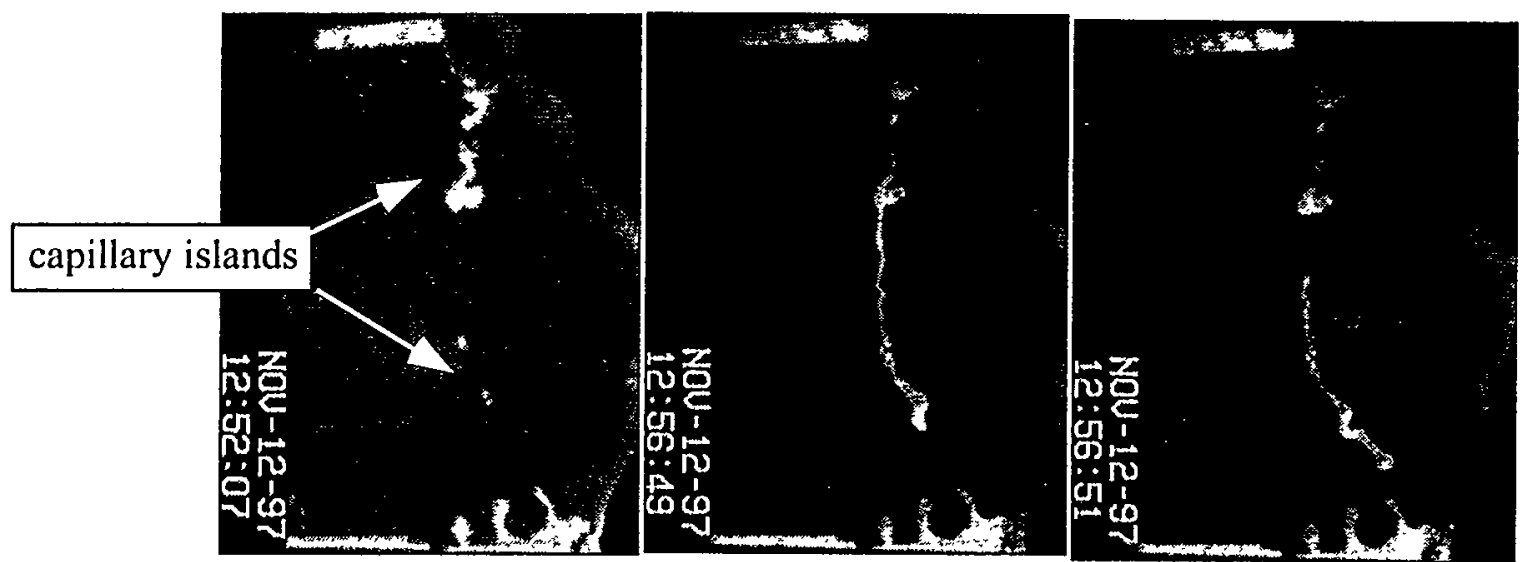

(b) $11 / 12$
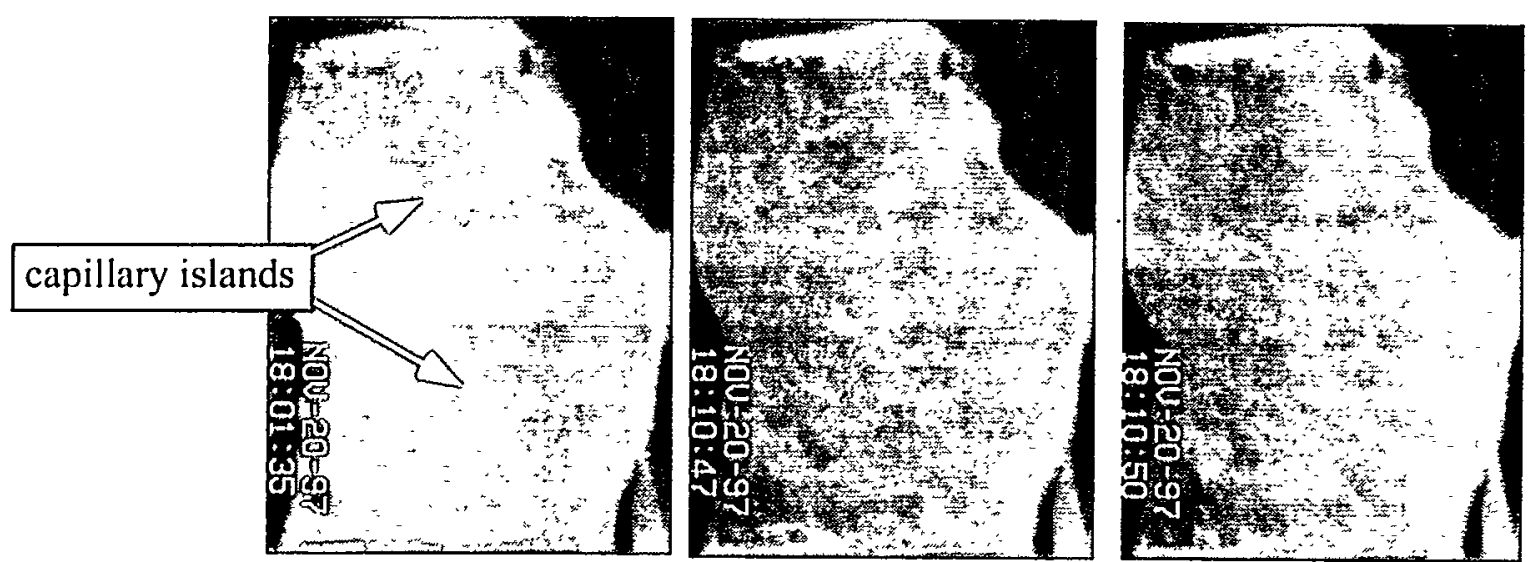

(c) $11 / 20$

Figure 19. Effect of biological growth on liquid seepage patterns. Images are of water seeping through the rock-replica open geocosm, where the rock fracture surface was innoculated with a mixed culture derived from defensible samples. Fluorescein was added to the water to promote visualization. Between $11 / 05$ (a) and $11 / 12$ (b), water vapor condensed in flow path creating "capillary islands", affecting flow behavior. The growth in the capillary island in (c) 11/20 corresponds to the increase in effluent bacteria and decrease in surface tension shown in Figure 18. 